\title{
Research Paper \\ The Effect of the Cognitive-Emotional-Social Working Memory Training Package on the Improvement of Metacognition and Emotional Creativity in Students
}

\author{
Mozhgan Hassani ${ }^{1}$, Mohammadali Nadi" ${ }^{* 2}$, Iilnaz Sajjadian ${ }^{3}$
}

1. Ph.D. Student of Educational Psychology, Isfahan Branch (Khorasgan), Islamic Azad University, Isfahan, Iran 2. Associate Professor, Department of Educational Psychology, Isfahan Branch (Khorasgan), Islamic Azad University, Isfahan, Iran 3. Assistant Professor, Department of Psychology, Isfahan Branch (Khorasgan), Islamic Azad University, Isfahan, Iran

Citation: Ghasemi M, Mirseifi Fard LS, Khalili F, Karami M. The effect of the cognitive-emotional-social working memory training package on the improvement of metacognition and emotional creativity in students. Quarterly Journal of Child Mental Health. 2020; 7(3): 108-127.

\section{http://dx.doi.org/10.52547/jcmh.7.3.10}

\section{A R T I C L E I N F O}

\section{Keywords:}

Cognitive-emotional social working memory training package, metacognition, emotional creativity, students

Received: 29 Aug 2018 Accepted: 30 May 2019 Available: 7 Dec 2020

\section{A B S T R A C T}

Background and Purpose: Considering the significance of working memory in academic performance, cognitive and metacognitive skills and creativity of students, this study was done to investigate the effectiveness of cognitive-emotional-social working memory training package on the improvement of metacognition and emotional creativity in female students with poor working memory.

Method: This study was a quasi-experimental research with control group pretest-posttest design. The study population included all the 10 to 12 year old female students at the $5^{\text {th }}$ grade of the primary school in Tehran city in the academic year 2015-2016. Among this population, a sample consisted of 40 students with poor working memory was selected by multi-stage (cluster) random sampling and then randomly assigned to the experimental or control group (20 students per group). Metacognition Questionnaire for Children (Bacow, 2009) and Emotional Creativity Inventory (Averill, 1999) were used to collect the data. Both groups were assessed by the mentioned tools at the pretest phase. Then, the experimental group received twenty 90 -min sessions of cognitive-emotional-social working memory training for three month, while the control group received no training. Data were analyzed by Analysis of Covariance using SPSS 20.

Findings: Data analysis showed that cognitive-emotional-social working memory training improved significantly metacognitive performance $(\mathrm{F}=89.18, \mathrm{P}<0.01)$ and emotional creativity $(\mathrm{F}=23.09$, $\mathrm{P}<0.01)$.

Conclusion: Based on the results of this study, it seems that the cognitive-emotional-social package of working memory due to having multidimentional and diverse tasks, is effective on the improvement of metacognition and emotional creativity in female students with poor working memory performance.

\footnotetext{
* Corresponding author: Mohammadali Nadi, Associate Professor, Department of Educational Psychology, Isfahan Branch (Khorasgan), Islamic Azad University, Isfahan, Iran.

E-mail addresses: Mnadi@khuisf.ac.ir
} 


\section{تأثير آموزش بسته شناختى - هيجانى - اجتماعى حافظه فعال بر بهبود فراشناخت و خلاقيت هيجانى دانش آموزان

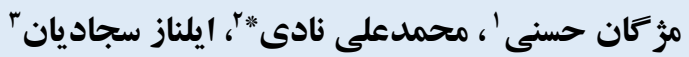

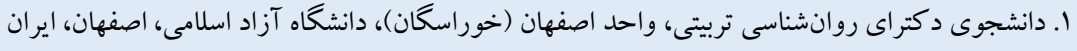

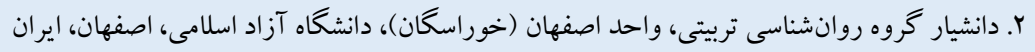

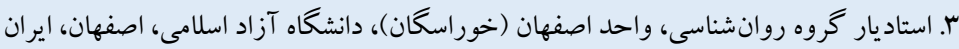

زمينه و هدف: با توجه به اهميت حافظه فعال در بهبود عملكرد تحصيلى، مهارتهاى شناختى و فراشناختى، و خلاقيت دانش آموزان، اين

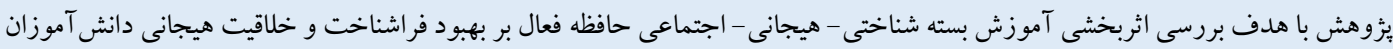
دختر با عملكرد ضعيف در حافظه فعال انجام شد. روش: اين مطالعه از نظر هدف، كاربردى و از نظر روش يثوهش، نيمه آزمايشى باطرح ييش آزمون و يس آزمون با دو گروه آزمايش وگو اه

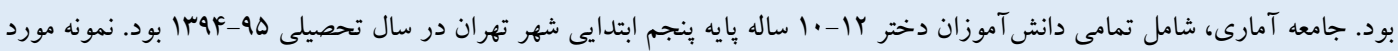

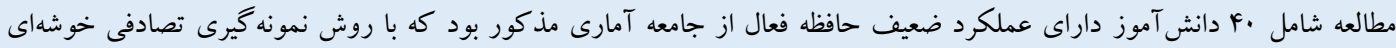

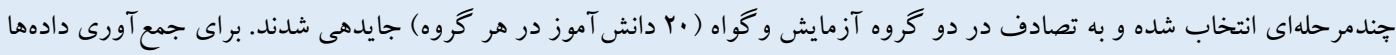

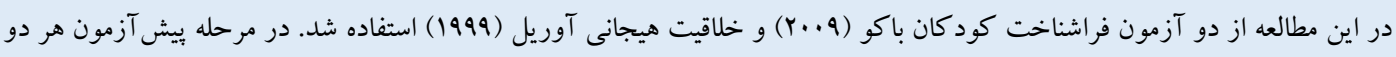

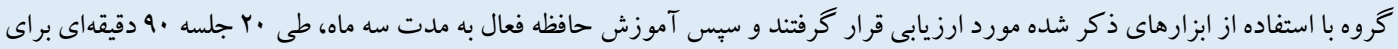

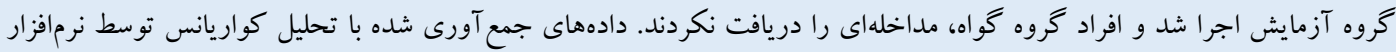
SPSS20 يافتها: نتايج تحليل دادهها نشان داد كه آموزش بسته شناختى- هيجانى- اجتماعى حافظه فعال به طور معنادارى باعث بهبود عملكرد

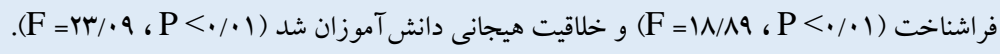
نتيجه كيرى: بر اساس نتايج اين مطالعه به نظر مىرسد بسته شناختى - هيجانى - اجتماعى حافظه فعال به دليل برخوردارى از تكاليف جند-

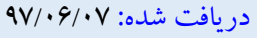
جانبه، متنوع، متعدد، و متناسب با توانايىهاى دانش آموزان بر بهبود فراشناخت و خلاقيت هيجانى دانش آموزان داراى عملكرد ضعيف در 
بـا بكار گيرى راهبردهاى فراشــاختى، ياد گيرنده تلاش مى كند تا از نظام

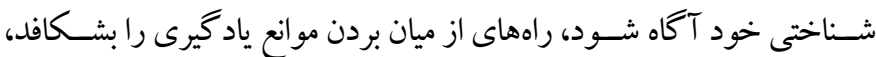

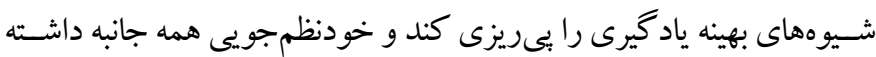
بـاشـــ (V). راهبردهـاى فراشـناختى موجب كارايى و بهبود فرايند بردازش اطلاعات در حافظه و ياد گيرى هدفمند و آكاهانه مى شــود و نقش مهمى در بهبود، انتقـال و تعميم يـادگيرى از يـك موقعيـت بـه موقعيـت جـديدتر و نيز نخهدارى يايدار مطالب ياد گرفنه شده دارد (11). درباره حافظه فعال يزوهش هاى موجود نشــان مىدهند كه نارسـايى در حافظه فعال موجب مشكلات در ياد گيرى مىشود و آموزش مستقيم حافظه فعال موجب بهبود عملكرد فر ايندهاى شـناختى و فراشـناختى مىشـود (YI). همجِنين در بسيارى از يُزوهشها به نقش كليدى فراشناخت و كنترل شناختى

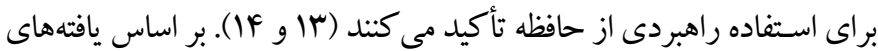

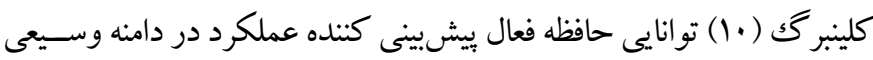
از فعاليتها و تكاليف شـناختى اسـت. در بززوهش سليمانى، عباسى و طغيانى (1) نيز انتقـال تغييرات حـافظه فعال به عملكردهاى شــناختى مختلف مورد تأييد قرار گرفته اسـت. كر كن، ريباى و كورنيش (19) راهبردهاى شناختى و فراشـناختى راطرحها يا روشهايى براى حل يكك مسـئله مىداند و معتقدند كه راهبردهاى شـناختى و فراشـناختى، اكتشـافهايى براى بردازش اطلاعات هسـتــد. افر اد در فراينـد كسـبـ اطلاعـات نيازمند نظمدهى به محر ككهاى خارجى فعاليت علمى و خلاق هسـتند و بدين منظور اسـتفاده از راهبردهاى شناختى اين نياز را تامين مى كند (IV).

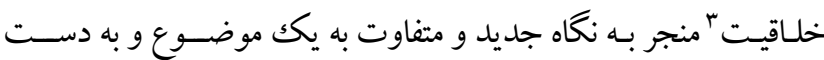
آوردن بينش جديد نسبت به ماهيت آن مىشـود. هنسى و امابيل (N|) معتقد هسـتند كه خلاقيت بديدهاى اجتماعى بوده و از نيازها و مقتضـيات جامعه و شـــايط خـانو اد كى بر مىخيزد. عدهاى ديخر ماند تورنس (19) معتقدند كه خلاقيـت يكك اثر شـــصـى اســ؛ يعنى به عواملى نظير انخيزش، هيجان،

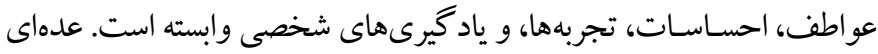

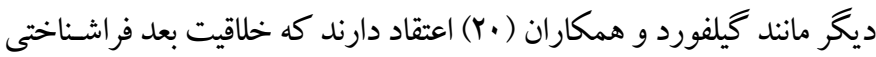
دارد و بـا فراينـدهـاى عـالى مـانــــ تفكر، هوش، تخيـل، و بردازش اطلاعات
بسيارى از مشكلات دانش آموزان در حافظه به مهارتهاى ضعيف شناختى و فر اشـناختى ' آنان مربوط است (1). راهبردهاى شناختى و فراشناختى به انتقال اطلـاعـات از حـافظه فعال بــه حافظه بلندمدت كمكك مى كنند (Y)؛ بنابراين حافظه فعال مركز آكاهى در نظام شــناختى و مخزن راهبردهاى شــناختى و فر اشـناختى اسـت (r). راهبردهاى شـناختى و فراشـناختى، رفتارها و افكارى هسـتند كه بر فرايند ذخيرهســازى و بازيافت مؤثرتر اطلاعات در حافظه تأثير

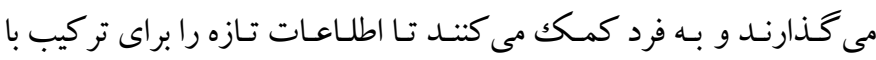
اطلاعات قبلاً آموخته شـده و ذخيرهسازى آنها در حافظه بلندمدت آماده كند

راهبردهاى فراشناختى، مهارتهاى بازبينى هستند كه در طى ياد گيرى و

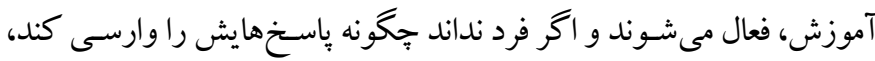

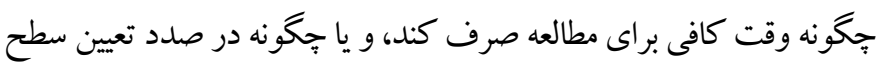

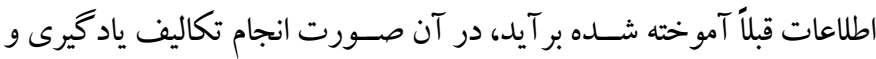
يـادآورى بـا دشـوارى بيشـتر انجـام مىشـود (F). بنـابر اين راهبردهــاى

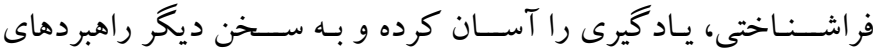
فراشــاختى ابزار هدايت و نظارت بر راهبردهاى شــناختى هسـتند (Y).

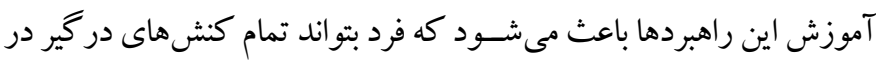

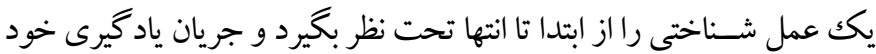
رابه كونهاى هدايت كند كه بهرهورى فرايندهاى ذهنىاش نسـبت به زمان و مكان در دسـترس افزايش يابد. اين كونه آموزش ها، ابزارهاى مفيدى براى تعميم ياد گيرى به موقعيتهاى مكانى و زمانى ديخر هستند (ه).

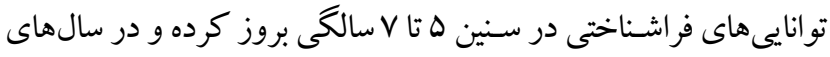

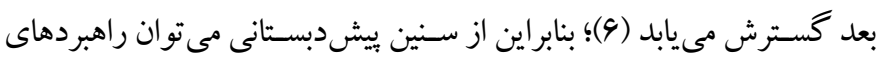
مناسـب فراشـناختى را به دانش آموزان آموزش داد و در دورههاى تحصسيلى بالاتر مىتوان آنها را بهبود و گسترش داد (V). يُزوهش هاى انجام شده نشان

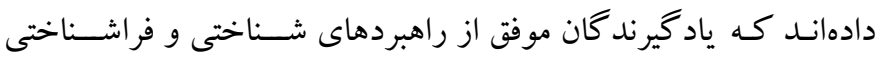

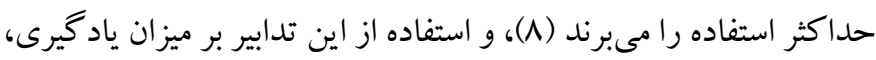
بيشرفت تحصيلى، سرعت خو اندن و در كك مطلب، سازماندهى و سرعت يردازش اطلاعات در حافظه فعال، و دقت و كار آيى حافظه فعال مى افزايد

1. Metacognitive

2. Working memory 
داسـتانهاى خود، هيجانات متناقض (مهربانى، تنفر، و سـردر گمى) را با

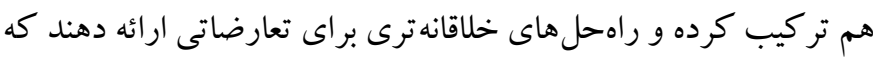
در ظاهر حل نشدنى هستند. افرادى كه خلاقيت هيجانى دارند كمتر تحت

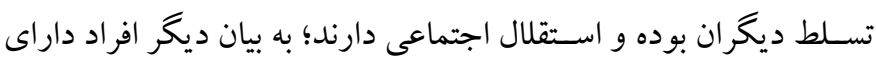

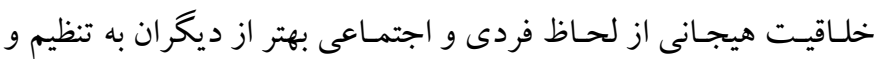
بروز هيجـانـات خود مى يردازنــ (YV). خلـاقيـت شــــاختى كه ســابقه طولـانى ترى از خلـاقيـت هيجـانى دارد توانيايى و ظرفيت فرد براى توليد

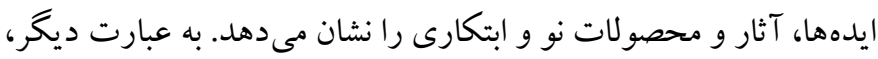

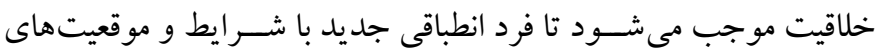
محيطى به گُنهاى غيرمرسوم ولى مفيد ويدا كند. از اين رو صاحبنظران

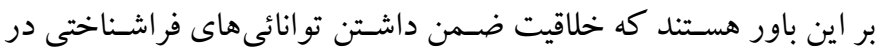
درون خويش با تخيل و واكرايى نيز همراه است (YN). بـا توجـه بـه تعـاريف و شــاخص هاى خلاقيت شـــناختى و خلاقيت

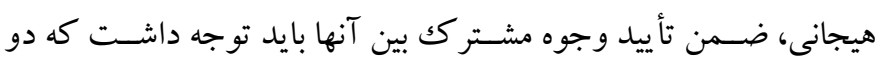

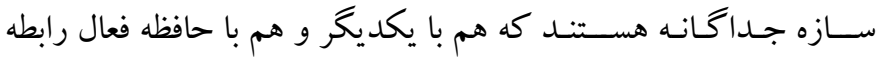

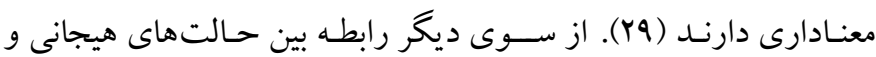

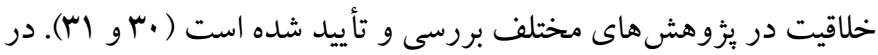

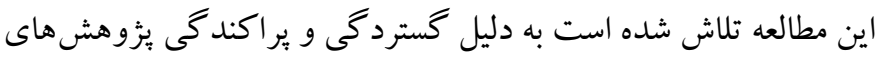
موجود درباره حافظه فعال، با استفاده از روش توصسيفى و مرور نظاممند مطالعات درباره حافظه فعال، به شــاسـايى مؤلفه هاى مؤثر برحافظه فعال يرداخته شود و سبس با استفاده از مؤلفههاى شناسايى شده، بسته آموزشى سـه بعدى شـناختى - هيجانى - اجتماعى حافظه فعال تدوين شــــ در بين

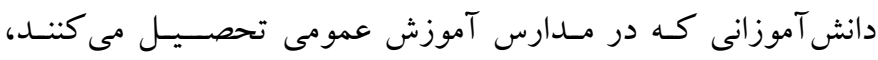

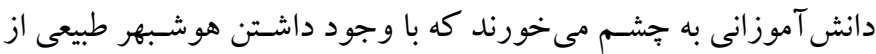

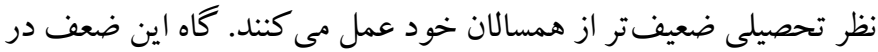
حيطه خواندن و نوشتن و كاه در محاسبه وجود دارد كه به علت عملكرد

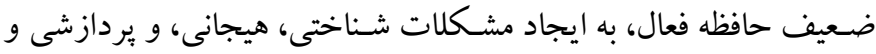

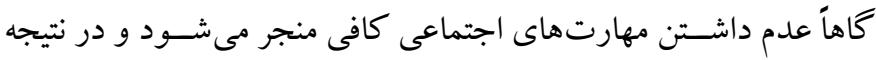
باعث مى شود دانش آموز از بيشرفت تحصيلى مناسبى برخوردار نباشد. از

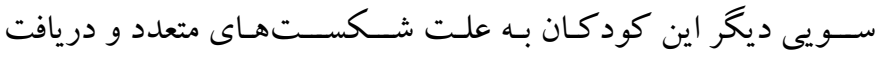

4. Effectiveness

5. Preparedredness
ارتباط دارد. بالاخره گروهى هم مانند استرنبر گ (YI) و ميهالى (YY) معتقدند كـه خلاقيت بديدهاى جندمتغيرى اســ؛ يعنى عواملى نظير جامعه، خانواده، شخصيت، و تو انايىهاى شناختى همزمان بر آن تأثير مى كذارند.

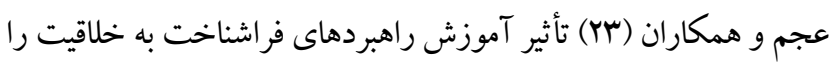
مثبت ارزيابى مى كنند. مقدم و همكاران (YF) نيز در يُزوهشى نشان دادند كه

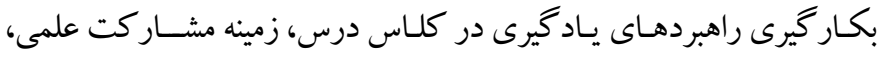

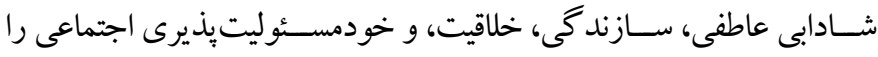

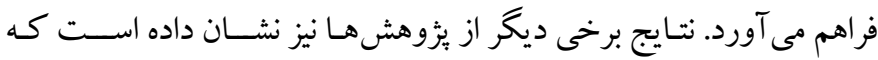

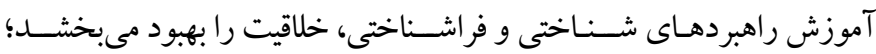
بنـابر اين بين راهبردهـاى فراشـــاختى و خلـاقيـت و حـافظه فعال رابطه مثبت

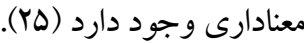
در مطالعات اخير درباره خلاقيت تقسيمبندى هاى متعددى انجام شده

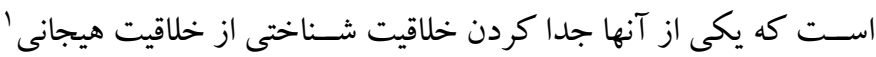
است. خلاقيت هيجانى را ابراز خود، به روشى جديد تعريف كردهاند كه نه

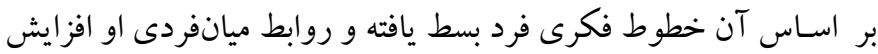

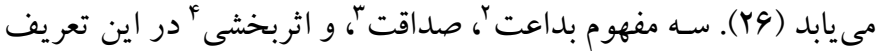

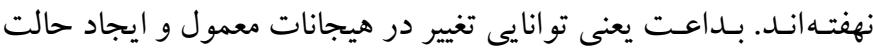

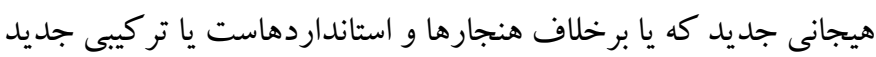

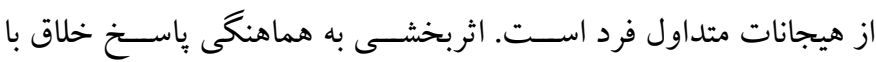

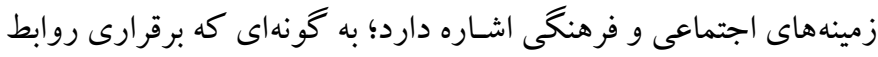
مطلوب با ديخران را ممكن كرده و بهبود شـيوه تفكر فردى را نيز فراهم

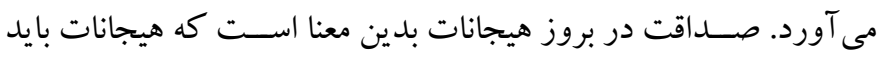

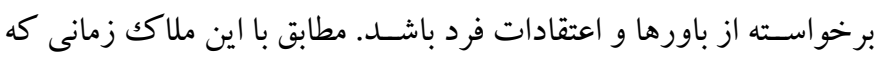
فرد متناسب با شرايط و موقعيت و برخلاف باور و احساس خود هيجاناتى

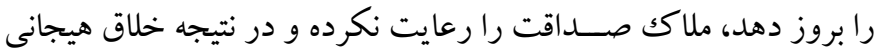

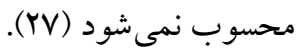

علـاوه بر ملـاككهاى فوق آوريل (Y4) معتقد اســت كه افر اد داراى خلاقيت هيجانى براى شـناخت هيجانات، وقت بيشترى صرف مى كنند و به هيجانات خود و ديخران توجه و دقت بيشترى دارند و گويى آمادكى هئى ذاتىه براى اين كـار دارنـد؛ بنابراين افراد خلاق هيجانى قادر هســتند در

1. Emotional creativity

2. Novelty

3. Authenticity 
و والــد از انجـام مطـالعه. همجنين معيارهاى خروج از مطالعه نيز عبارت بودند از: انصراف دانش آموز يا والد از شركت در مطالعه و غيبت بيش از از دو جلسه دانش آموز در روند مداخله.

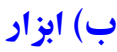

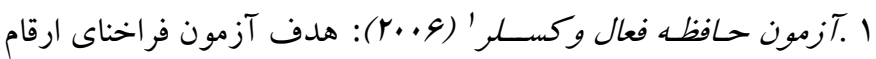

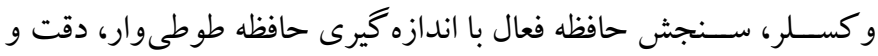
جابجايى الكوهاى تفكر اسـت. ارقام مسـتقيم، حافظه طوطىوار، و ارقام معكوس توانايى تمركز، صبر و انعطاف يذيرى را مىسنجند (r/). در اين يُزوهش از وير ايش رايانهاى آزمون كه داراى جهار مرحله است، استفاده

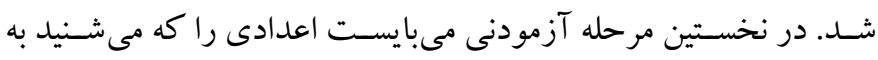
خـاطر ســبرده و با اتمام هر رديف، اعداد مورد نظر را به همان ترتيب از

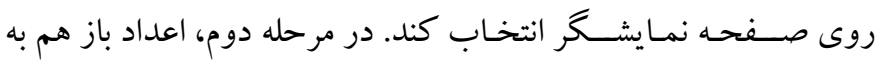
صورت شنيدارى اما معكوس بيان مىشود. در مرحله سوم بايد ارقامى كه روى صــفحه نمايش ظاهر مى شــــند به همان ترتيب از صــفحه نمايش

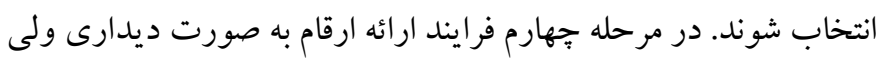

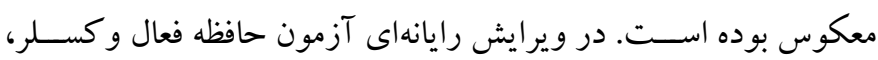
نمره هر آزمودنى شـامل تعداد باسـخهاى صحيح است. روايى محتو ايى رنى

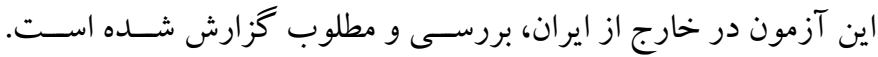

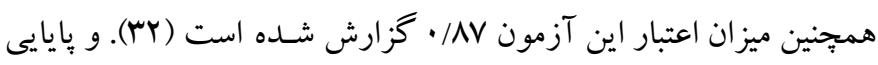

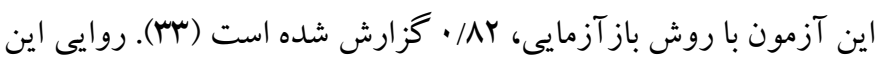

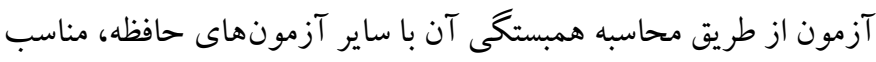

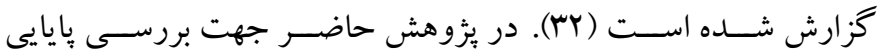

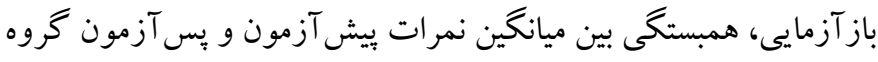

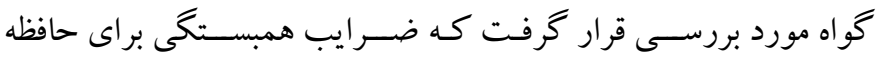

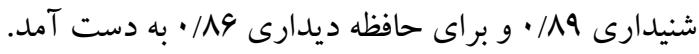

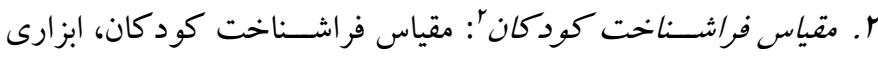

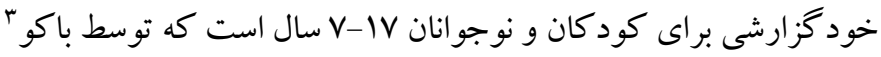

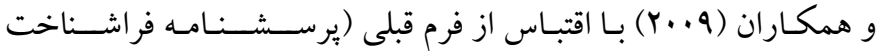

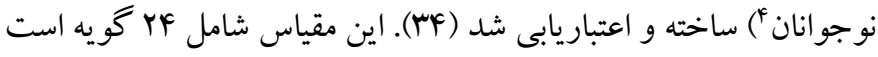
كـه آزمودنى در يـك مقيـاس ه درجـهاى (از كـاملاً مخالفم =ا اتا كاملاً

3. Bacow

4. Metacognitions Questionnaire for Adolescents (MCQ-A)
برجسـبـهاى گوناگون توسط معلمان و همكلاسـىها، بيامدهاى ناكوار ديخرى جون كاهش اعتماد به خود و سـاير مشكلات روانشناختى را نيز

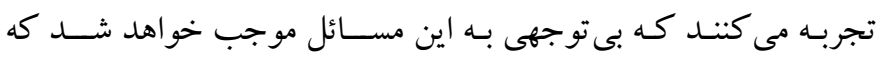
دانش آموزان بيشـترى از جرخه آموزش عمومى و رسـمى خارج شـوند. بنابراين هدف از انجام اين بزوهش اين بوده اسـت كه مشـخص شود كه

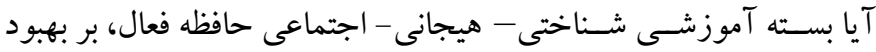
فراشناخت و خلاقيت هيجانى دانش آموزان دختر، اثربخش است؟

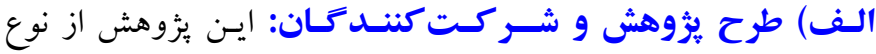

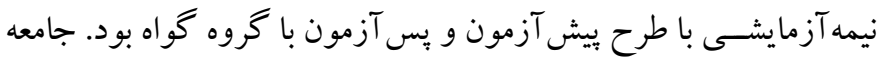

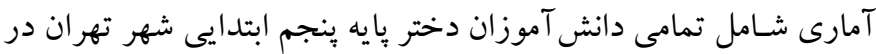

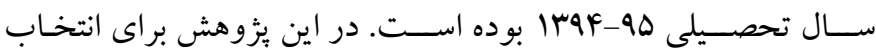

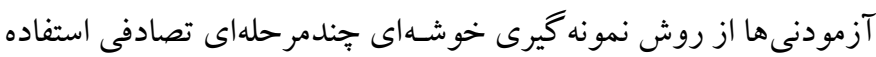

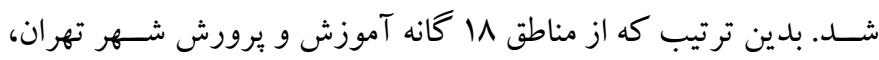

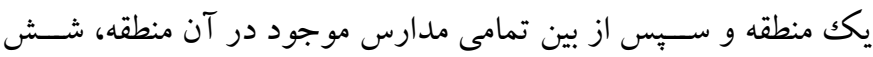
مدرسه به صورت تصادفى انتخاب شد. بِ از كسب مجوز از آموزش و

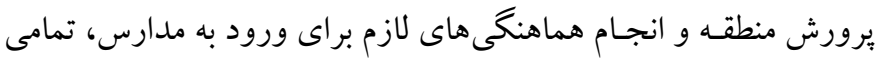

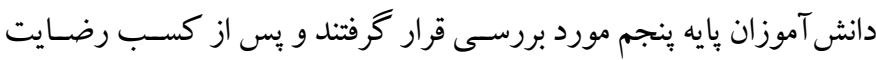

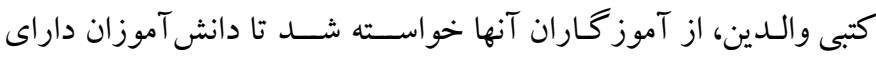

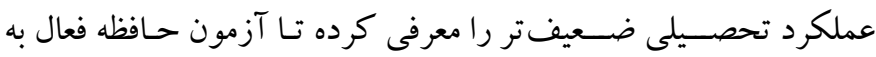

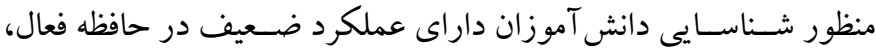

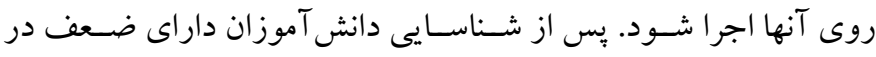

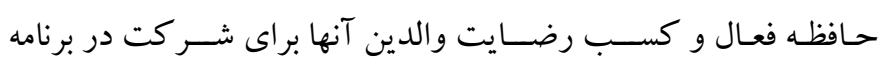

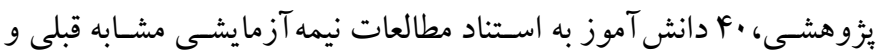
حجم نمونه بيشــنهادى براى مطالعات نيمه آزمايشـى در كتب آمارى، به صورت تصادفى انتخاب شدند و به صورت كاملاً تصادفى به قيد قرعه در

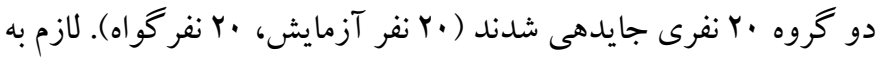

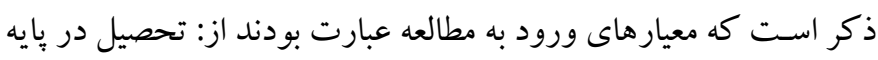

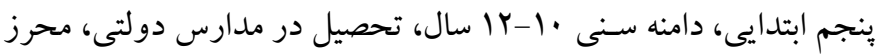
بودن تشخيص عملكرد ضعيف حافظه فعال، همكارى و رضايت كودك 
خـارجى آوريل از طريق تحليل عامل تأييدى، ســاختار سـه عاملى اين

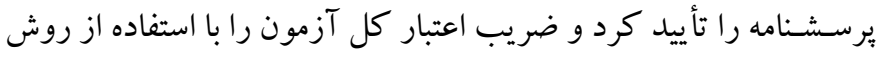

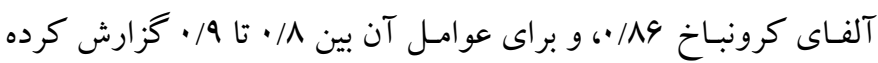

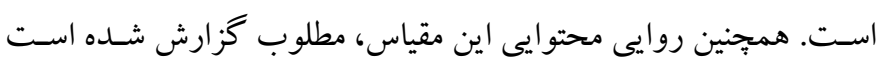

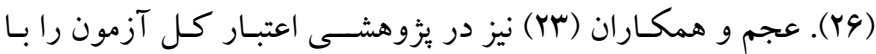

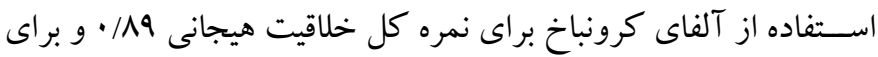

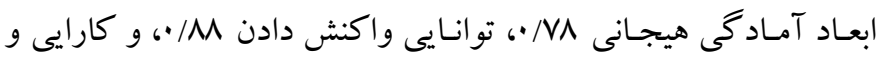

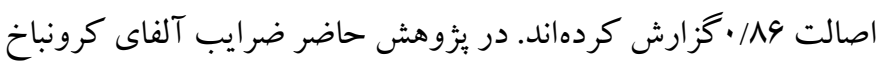

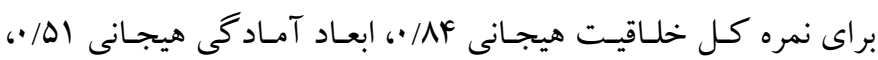
توانيى واكنث دادن NA/، و و كارايى و اصالت V/ • به دست آمده است.

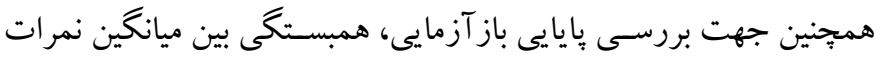

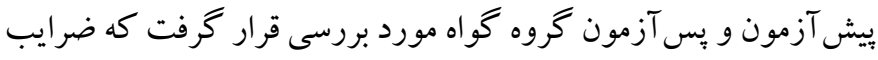

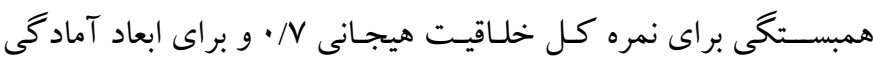

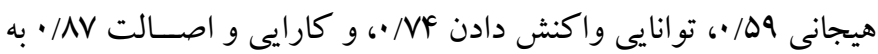
دست آمده است. ج) برنامه مداخلهاى: در مرحله اول بثزوهش ابتدا به منظور شـــاسـايى مؤلفه هاى اثر كذار بر حافظه فعال جهت تدوين بستهـ آموزشى شناختى هيجانى - اجتماعى حافظه فعال از روش توصيفى و مرور نظاممند استفاده

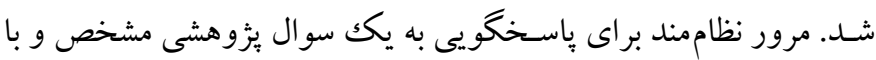

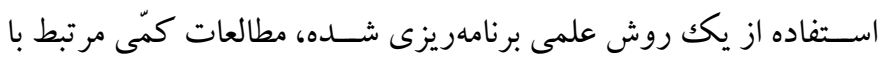
سـوال مورد نظر را مورد بررسـى قرار مىدهد. ســاختار كلى يكك مرور نظاممند عبارت است از: جستجو و يافتن مطالعات كمى مربوطه، ارزيابى ترونى

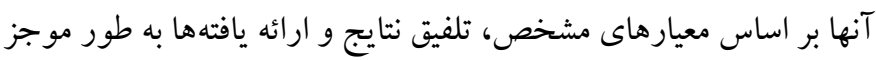
و شـفاف (4)). در يزوهش حاضـر بازه زمانى انتخاب شده براى جستجو

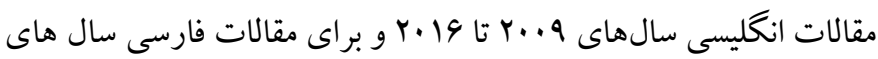

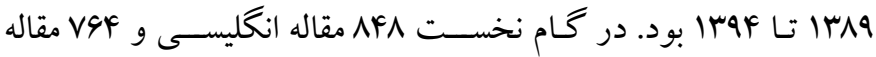
فارسى وارد يُزوهش شـدند و در كام آخر (جهارم)، إب مقاله انگليسى و و

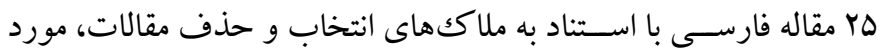

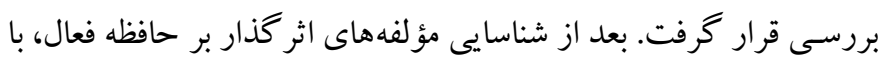

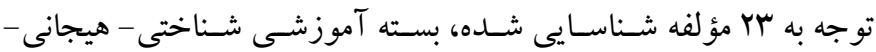

4. Superstitious beliefs

5. Emotional creativity inventory

6. Avrill
موافقم =D) به آن ياسـخ مى دهد. همجنين اين ابزار شـامل F اخردمقياس عقايد مثبت درباره نخرانى يا همان فرانخرانى مثبت' (كويههاى ل، V، 9،

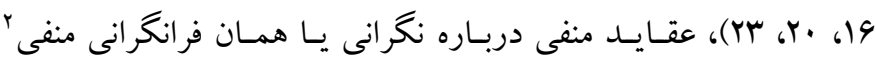

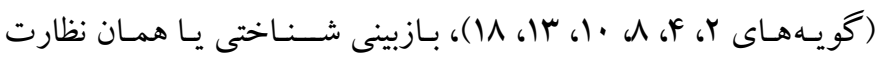

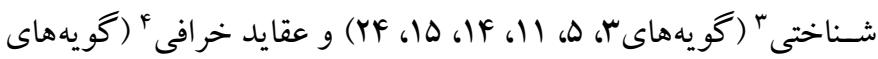

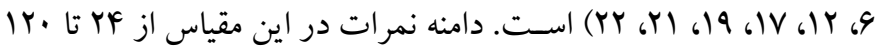
اسـت كه نمرات بيشـتر نشـان دهنده فعاليت فراشناختى منفى بالاتر است.

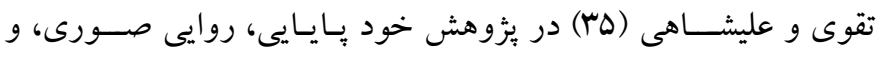
محتوايى مقياس فراشـناخت كود كان را مورد ارزيابى و تأييد قرار دادند. ضـرايب آلفاى مقياس فراشـناخت براى نمونه غير بالينى، براى نمره كل

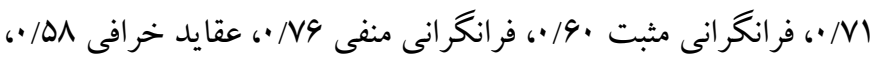

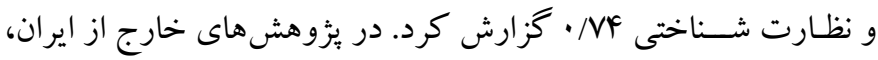
روايى اين مقياس مطلوب كزارش شــده اسـت و ميزان يايايى براى نمره

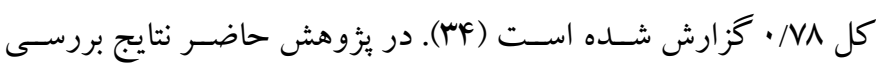
همسانى درونى با استفاده از ضريب آلفاى كرونباخ براى نمره كل IFF •،

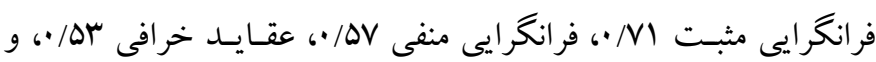

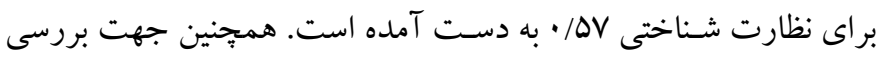
يايايى باز آزمايى همبستخى بين ميانگين نمرات بيش آزمون و پيس آزمون

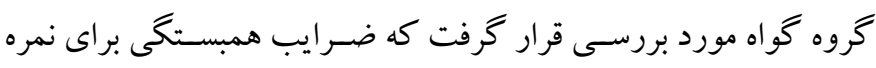

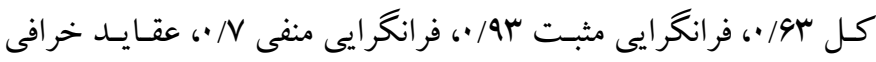
191•، و وبراى نظارت شناختى 19 / • به دست آمده است.

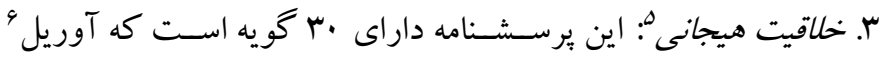
(1999) به منظور اندازه گيرى خلاقيت هيجانى و شـامل سـه بعد آمادكى

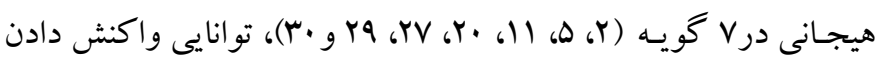

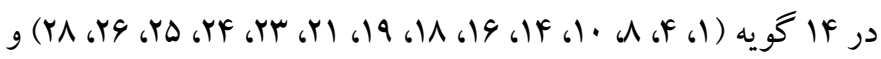

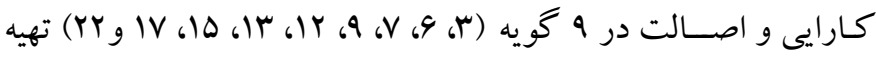
كرده است. يُاسخ به گويه ها در طيف ه درجهاى ليكرت (خيلى كمتر =

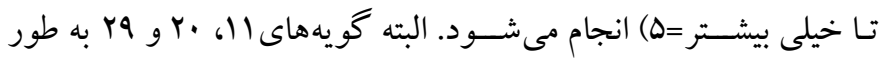
معكوس نمره گذارى مىشــوند. نمره يايين نشـان دهنده خلاقيت هيجانى كم و نمره بالاتر نشــان دهنده خلاقيت هيجانى زياد اســت. در مطالعات

1. Positive meta-worry

2. Negative meta-worry

3. Cognitive monitoring 
متشــكل از هـ دانش آموز دختر (پـايه ينجم ابتدايى شــهر تهران) داراى

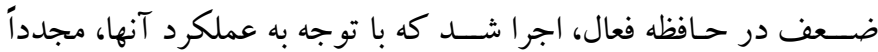
تغييرات لازم انجام شد. در ادامه محتواى جلسات بسته آموزشى شناختى هيجانى - اجتماعى حافظه فعال به صورت خلاصه در جدول ا ارائه شده

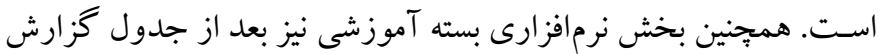

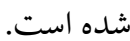

اجتماعى حافظه فعال تدوين شـد و سـبس با نظرخو اهى از · ا متخصصص در حيطه حافظه فعال، عنوان و محتو اى هر جلسه بسته آموزشى شناختى هيجانى - اجتماعى حافظه فعال بررسى شـــ تا نظرات موافق و مخالف و

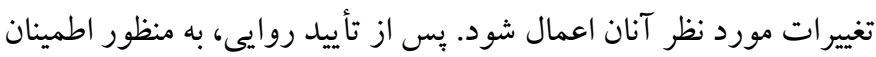

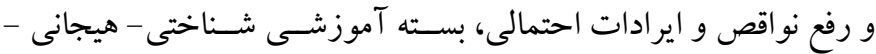
اجتمـاعى حـافظه فعـال در مطـالعه مقـدمـاتى بر روى يـك كروه نمونه

جدول ا: محتواى جلسات بسته آموزشى شناختى - هيجانى - اجتماعى حافظه فعال

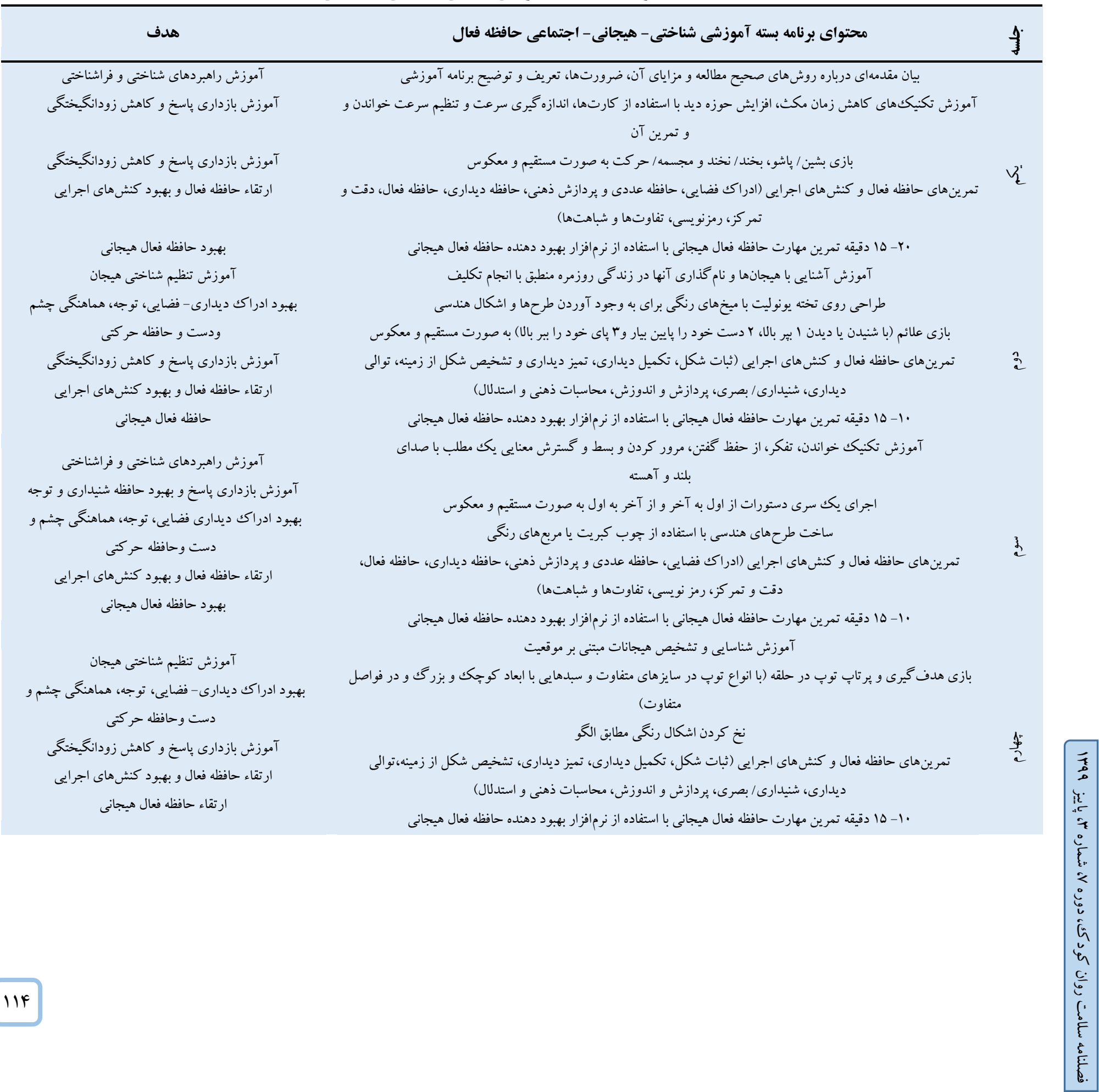




\section{آموزش راهبردهاى شناختى و فراشناختى

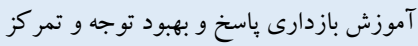

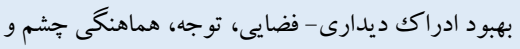

دست وحافظه حر كتى

ارتقاء حافظه فعال و بهبود كنشهاى اجرابى

بهبود حافظه فعال هيجانى

آموزش تنظيم شناختى هيجان

بهبود ادراك ديدارى - فضايى، توجه، هماهنكى جشم و هيجان

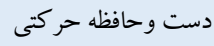

آموزش بازدارى باسخ و كاهش زودانكيختخى و بهبود

توجه و و تمركز

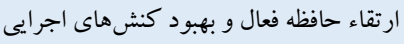

ارتقاء حافظه فعال هيجانى

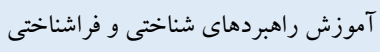

آموزش بازدارى ياسخ، بهبود حافظه شنيدارى، حركتى وركي،

توجه و و تمركز

يهبود ادراكك ديدارى - فضايى، توجه

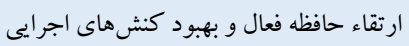

آبهوبود حافظه فعال هيجانى

آموزش تنظيم شناختى هيجان

بهبود ادراكك ديدارى - فضايى، توجه و تمر كز، بازدارى

باسخ

و هماهنكى جشم و دست بالتخ

آموزش بازدارى باسخ و كاهش زودانكيختخى و و بهبود

توجه و تمركز

ارتقاء حافظه فعال و بهبود كنشهاى اجركائى

ارتقاء حافظه فعال هيجانى

آموزش راهبردهاى شناختى و فراشناختى

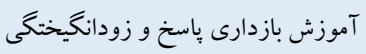

بهبود ادراكك ديدارى - فضايى، توجه و تمركز

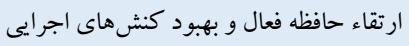

بهبود حافظه فعال هيجانى

آموزش تنظيم شناختى هيجان

آموزش بازدارى ياسخ و كاهش زودانكيختخى و بهبود

توجه و تمركز

بهبود ادراكك ديدارى - فضايى، توجه و وتمركز

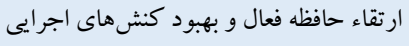

ارتقاء حافظه هيجانى
آموزش و كار با دانش آموز درباره انتخاب بخشهاى مهم و بخش بخش كردن آنها ، برد ، خط كشيدن زير آنها، خلاصه كردن

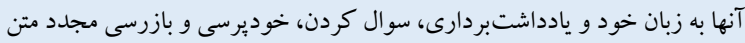

$$
\text { تمرين دقت و توجه با استفاده از اشكال هندسى بردي }
$$

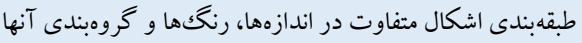

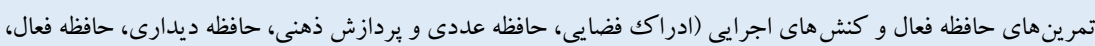

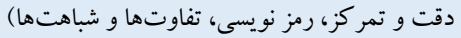

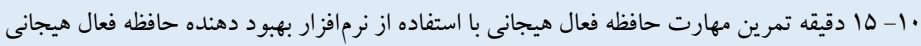

آموزش شناسايى و تشخيص هيجانات مبتنى بر خواسته

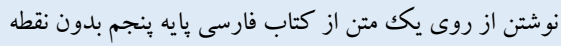

بازى دومينو

تمرينهاى حافظه فعال و كنشهاى اجرايى (ثبات شكل، تكميل ديدارى، تميز ديدارى، تشخيص شكل از زمينه، توالى دئى

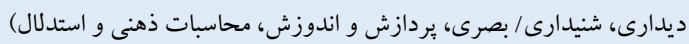

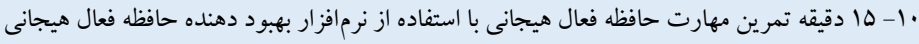

آموزش سازماندهى، نقشه مفهومى و الكوى مفهومى براى استفاده از مطالب آمو خته شده و استفاده از آنها در حل مسئل

$$
\text { بازى بينخو }
$$

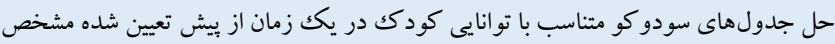

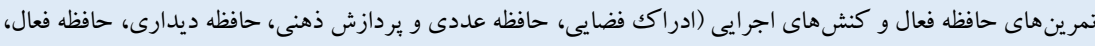

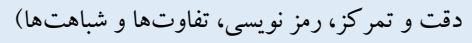

• ا- ها دقيقه تمرين مهارت حافظه فعال هيجانى با استفاده از نرمافزار بهبود دهنده حافظه فعال هيجانى

آموزش شناسايى و تشخيص هيجانات مبتى بر باور

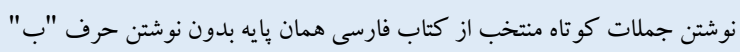

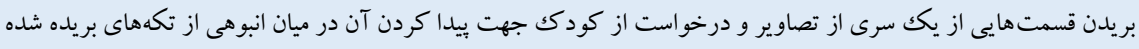

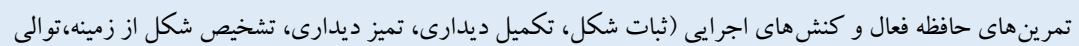

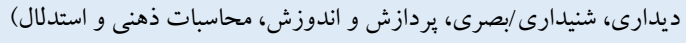

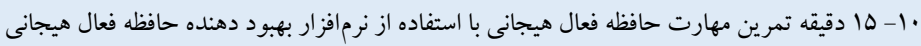

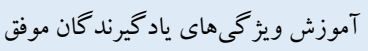

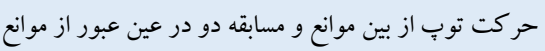

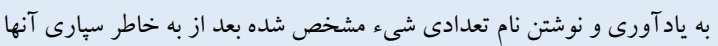

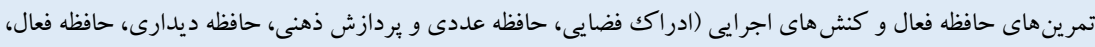

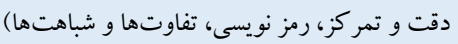

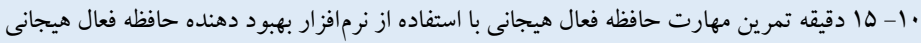

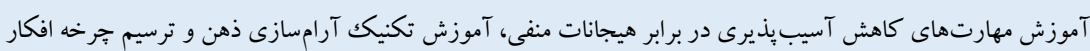

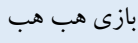

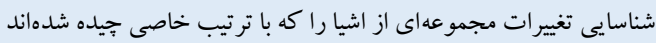

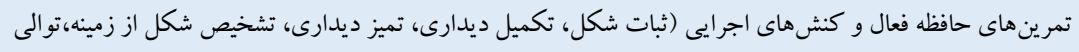

ديدارى، شنيدارى/بصرى، يردازش و اندوزش، محاسبات ذهنى و استدلال)

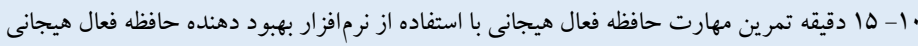




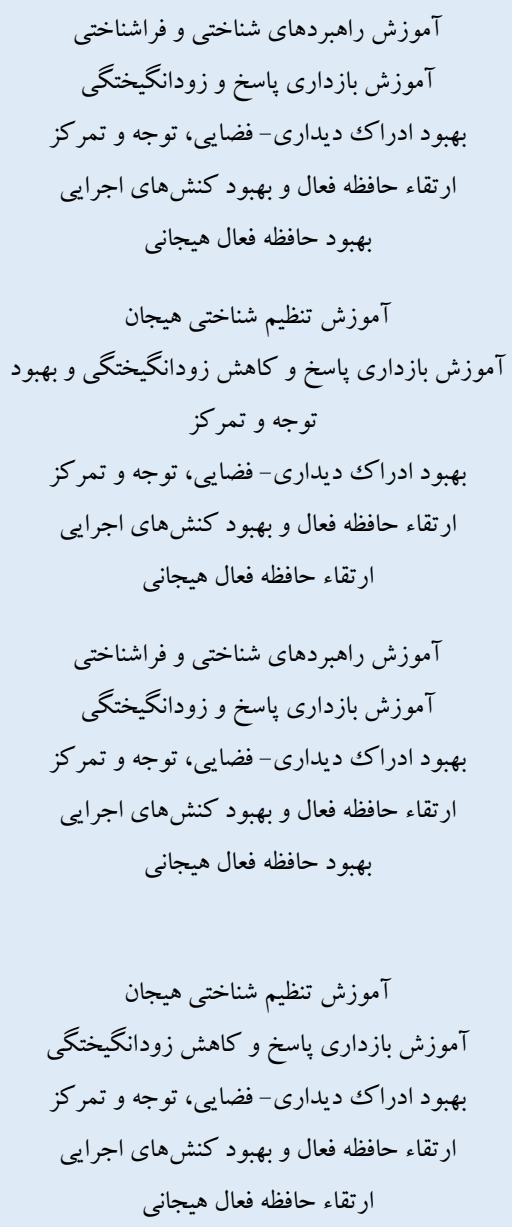

\section{آموزش روش مطالعه مشار كتى و روش ير سيدن دوجانبه}

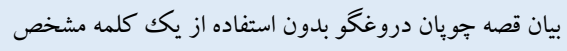

بازى با كارتهاى كلمات

تمرينهاى حافظه فعال و كنش هاى اجرايى (ادراكث فضايى، حافظه عددى و بردازش ذهنى، حافظه ديدارى، حافظه فعال،

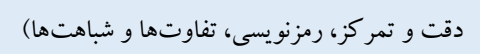

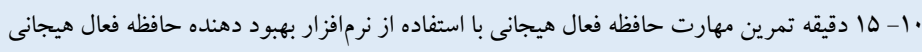

$$
\begin{aligned}
& \text { آموزش تكنيك جداسازى هيجانات غم، ترس و خشم از مشكل }
\end{aligned}
$$

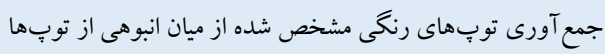

$$
\begin{aligned}
& \text { بازى با مقو اهاى رنكى و طراحى اشكال هندسى ييجيده }
\end{aligned}
$$

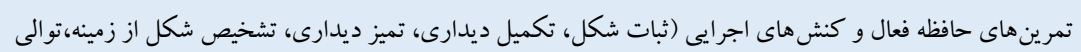

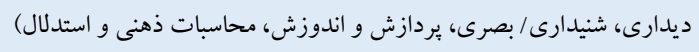

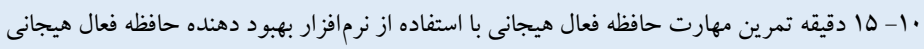

$$
\text { آموزش تكنيك حل مسئله }
$$

يريدن داخل مربعهاى رنخى با اعداد مشخص و راهرفتن روى يكك يا با حفظ تعادل

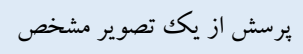

تمرين هاى حافظه فعال و كنشهاى اجر ايى (ادراكك فضايى، حافظه عددى و يردازش ذهنى، حافظه ديدارى، حافظه فعال،

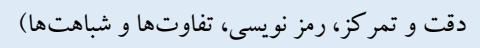

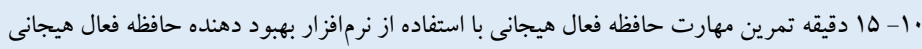

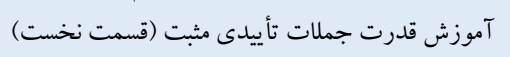

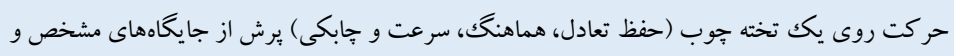

$$
\text { حفظ تعادل با ثبت زمان }
$$

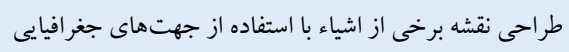

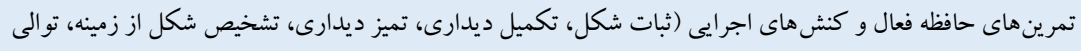

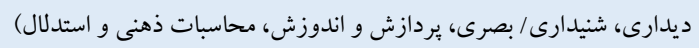

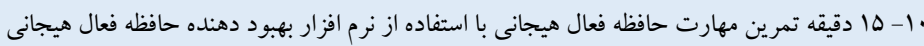

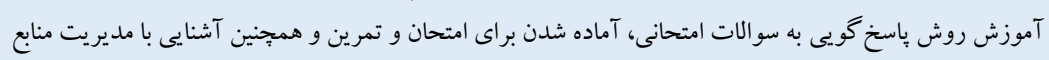

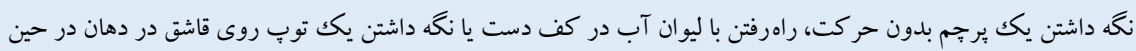

$$
\text { راه رفتن }
$$

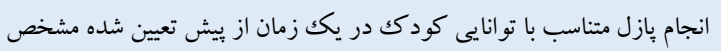

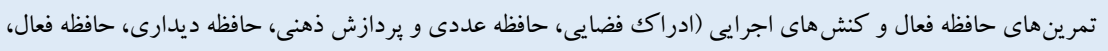

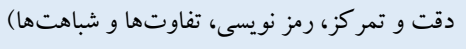

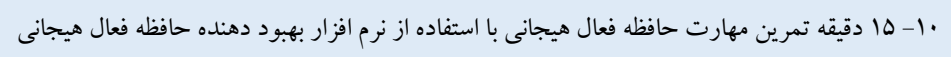

$$
\text { آموزش قدرت جملات تأييدى مثبت (قسمت دوم) }
$$

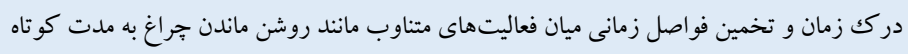

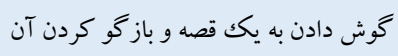

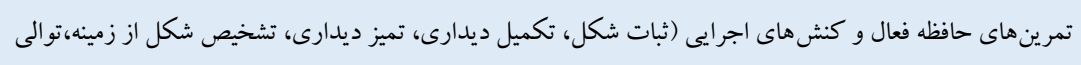

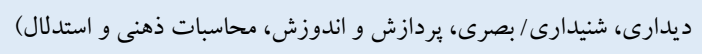




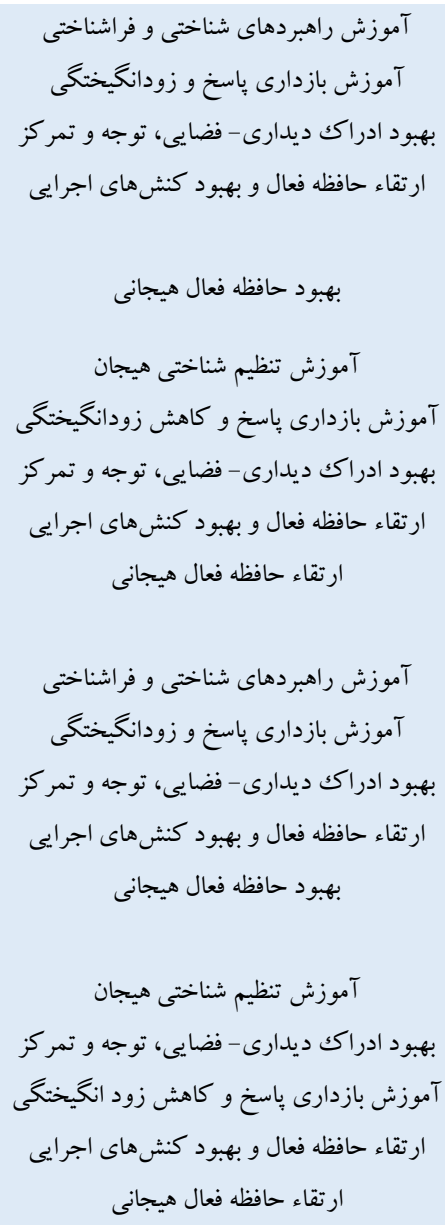

\section{آموزش راهبردهاى رابطهاى از قبيل تصوير سازى ذهنى، روش مكانها، كلمه كليد و سر وازه}

آموزش جفتهاى متضاد

بازى با خرتكه

تمرينهاى حافظه فعال و كنش هاى اجرايى (ادراكك فضايى، حافظه عددى و يردازش ذهنى، حافظه ديدارى، حافظه فعال، دقت و

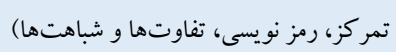

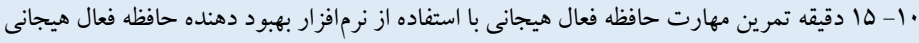

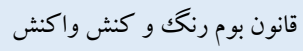

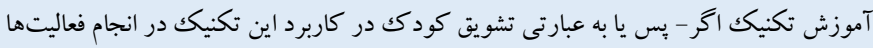

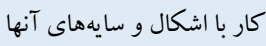

تمرينهاى حافظه فعال و كنشهاى اجر ايى (ثبات شكل، تكميل ديدارى، تميز ديدارى، تشخيص شكل از زمينه، تو الى إنى انهاي

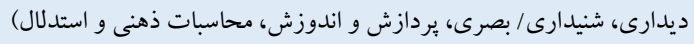

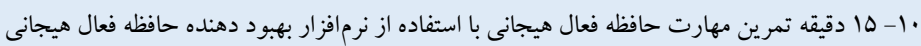

آموزش روش يس بس بحتام

آموزش باسخ گويى به محرك آماج و فقدان ياسخ گويى به محرك كتهاى غير آماج

بازى بطرى هاى رنخى

تمرينهاى حافظه فعال و كنشهاى اجرايى (ادراكك فضايى، حافظه عددى و بردازش ذهنى، حافظه ديدارى، حافظه فعال، دقت و

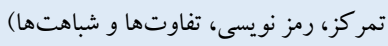

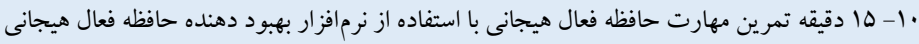

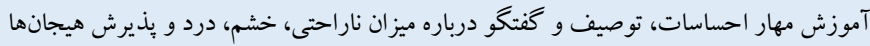

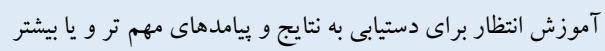

نخ كردن اشكال هندسى مطابق الكو

تمرين هاى حافظه فعال و كنش هاى اجرايى (ثبات شكل، تكميل ديدارى، تميز ديدارى، تشخيص شكل اند از زمينه، توالى

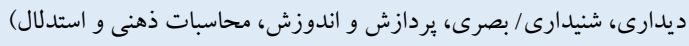

• ا- ها دقيقه تمرين مهارت حافظه فعال هيجانى با استفاده از نرمافزار بهبود دهنده حافظه فعال هيجانى
در بخش آموزش بـا كمـك رايـانه از نرم افزار آموزش حافظه فعال هيجانى ' اسـتفاده شــده اسـت. اين نرم افزار يكى از بـ بـ مؤلفه مؤثر در حافظه فعال شــناسـايى شــــه با اســفاده از روش علمى مرور نظاممند

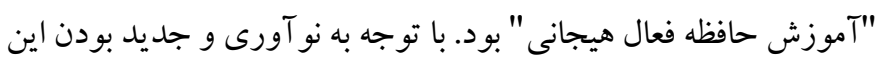

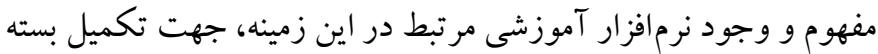
آموزشى شناختى - هيجانى - اجتماعى حافظه فعال، نسخه فارسى نرمافزار

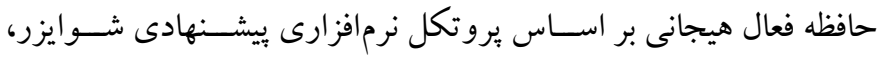

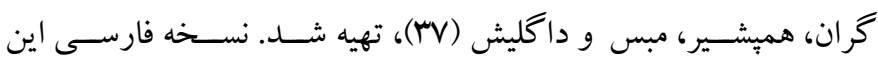

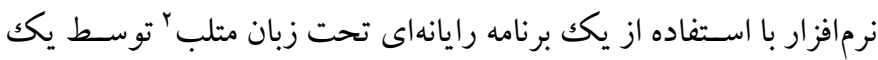

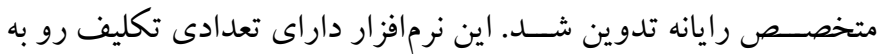
عقب هيجانى اسـت كه به طور همزمان تصويرى به مدت لـ له ميلى ثانيه

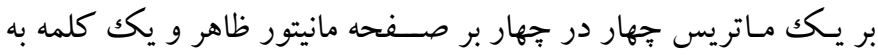


صورت خود كار به يكك مرحله بايين تر مىرود. بنابر اين شركت كنند گان

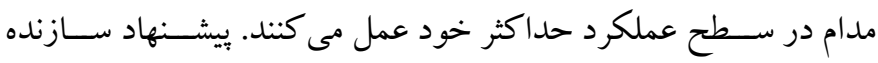

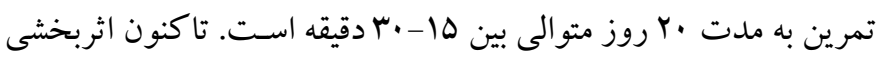

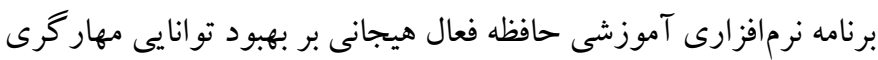

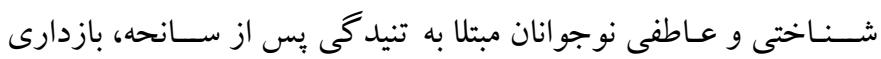
رفتـارى مبتلـايان به اختلال وســـواس بى اختيارى، مهار شــناختى افراد با اضـطر اب صــفت بالا، بهبود كنش هاى اجرايى نوجوانان مبتلا به اختلال

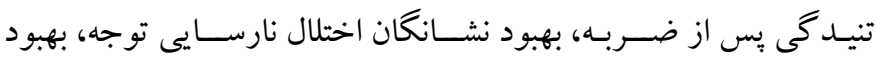

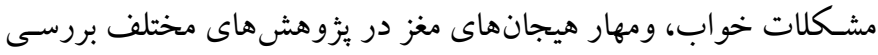

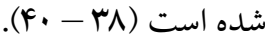

فضـايى هدف، باســخ نادرسـت بدهد يا باســخ ندهد شـكلكى با جهره ناراحت به رنغك قرمز و در صورت باسخ صحيح شكلكى با جهره خندان

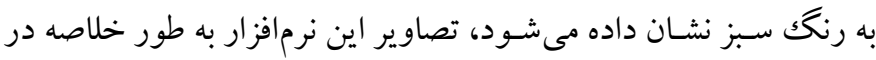
شكل ا نشان داده شده است.

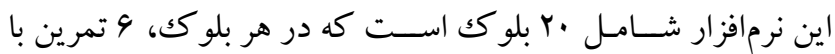
محر ككهاى ديدارى و شــنيدارى ارائه مىشــود. براى اينكه آزمودنىها

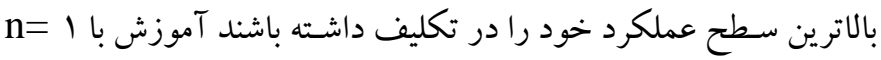
شـروع مى شود و جنانجه آزمودنى به سه تمرين متوالى به دقت و درستى

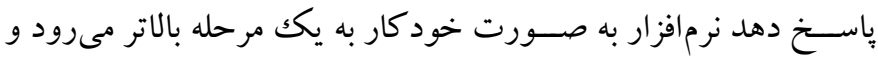

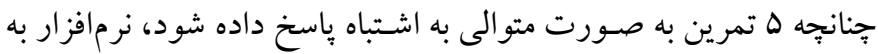

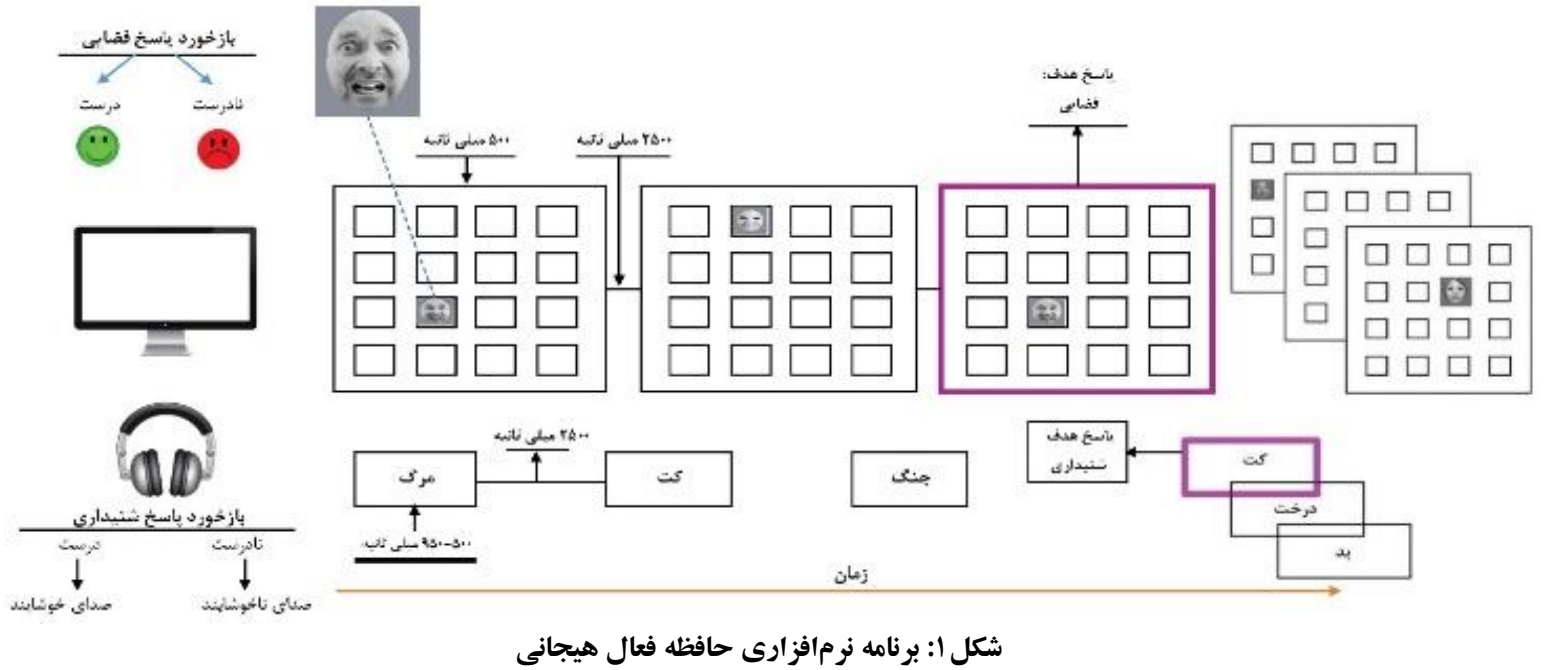

بـا جهار روش ســخنرانى، تكـاليف مداد كاغذى، بازىهاى هدفمند، و

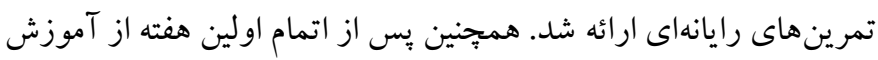

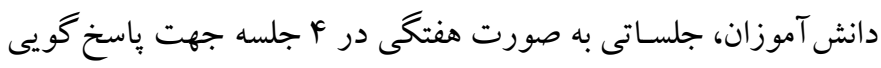

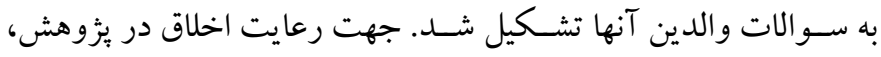
رضايت دانش آموزان و والدين آنها براى شركت در برنامه مداخله كسب

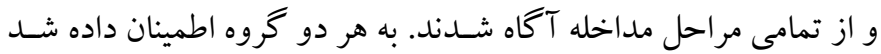

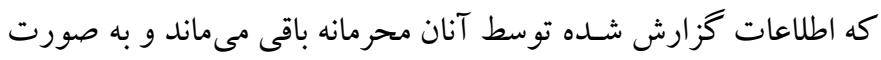

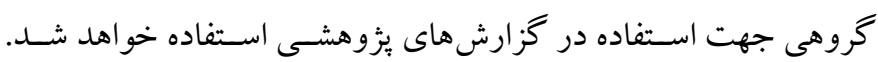

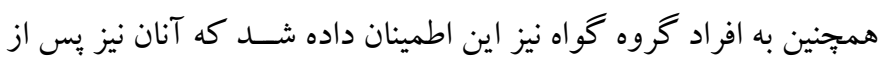
اتمام فرايند يزووهشى، اين مداخلات را دريافت خو اهند كرد. بعد از اتمام جلسـات آموزش، بس آزمون در هر دو گروه نمونـه (آزمايش و گتواه)
د) روش اجرا: يس از همـاهنكى للـازم بـا آموزش و يرورش و كسـبـ

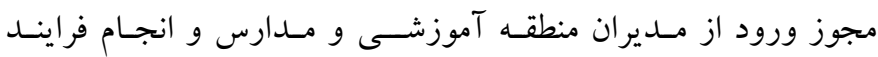

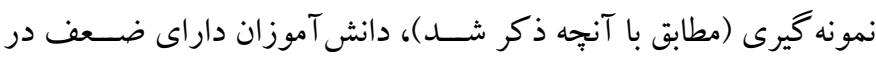

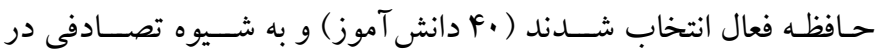

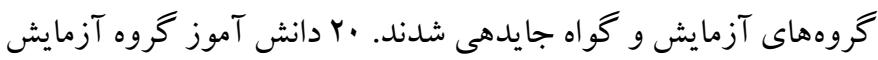

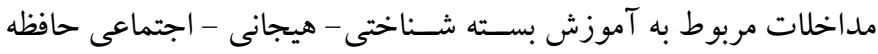

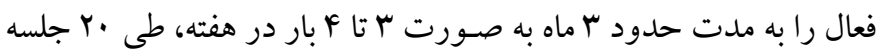

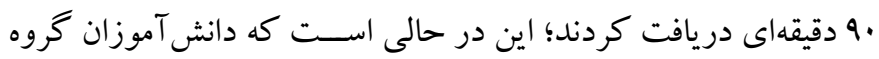

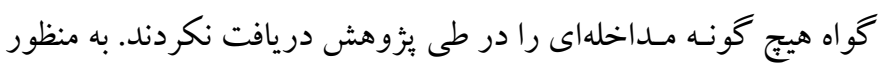

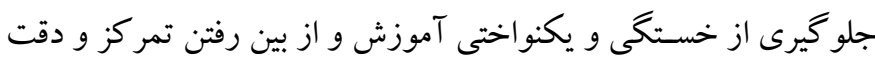

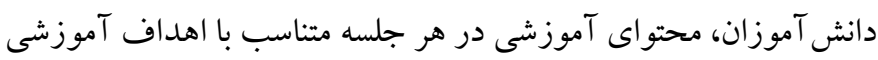




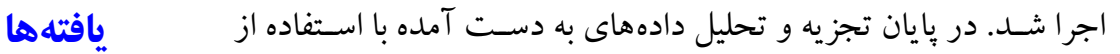
ميانگين و انحر اف استاندارد و همجِنين نرمال بودن نمرات دانش آموزان تحليل كوواريانس انجام شد.

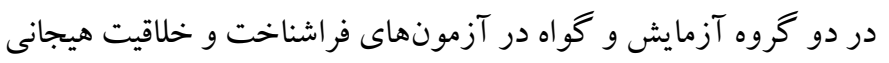

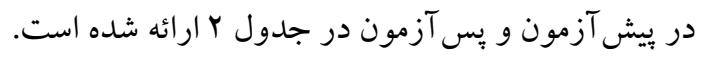

جدول ז: شاخصهاى توصيفى و آزمون نرمال بودن نمرات بيش آزمون و بس آزمون در دو كروه آزمايش و كواه (تعداد: •r)

\begin{tabular}{|c|c|c|c|c|c|c|c|}
\hline Sig & Shapiro-Wilk & انحر اف استاندارد & ميانغين & كروه & وضعيت & متغير & آزمون \\
\hline - MYY &.$/ 999$ & $r / \mu r$ & $M / V$ & آزمايش & \multirow{2}{*}{ ييش آزمون } & \multirow{4}{*}{ نظارت شخصى } & \multirow{28}{*}{ فراشناخت } \\
\hline.$/ .94$ &.$/ 911$ & $F / F \Lambda$ & IV/VD & كواه & & & \\
\hline$\cdot / 1 \Delta \Delta$ &.$/ 94$ & $r / 4 i$ & $\mid r / f$ & آزمايش & \multirow{2}{*}{ يس آزمون } & & \\
\hline$\cdot / \cdot \Delta V$ & $\cdot / 9 \cdot V$ & r/AG & $19 / 90$ & كواه & & & \\
\hline$\cdot / \cdot v r$ & $\cdot / 911$ & $F / \wedge \Delta$ & $19 / 4 \Delta$ & آزمايش & \multirow{2}{*}{ ييش آزمون } & \multirow{4}{*}{ فرانگر انى مثبت } & \\
\hline$\cdot / \cdot \Delta r$ & $\cdot / 9 \cdot 4$ & $\Delta / \cdot q$ & $1 Y / 9$ & كواه & & & \\
\hline$\cdot / \Delta F A$ &.$/ 990$ & $r / r v$ & $11 / 4 \Delta$ & آزمايش & \multirow{2}{*}{ يس آزمون } & & \\
\hline$\cdot 1 \cdot 1$ &.$/ 910$ & $F / \Delta \Lambda$ & $\mid r / F \Delta$ & كواه & & & \\
\hline$\cdot / 4 \cdot \Delta$ & . $/ 9 \Delta r$ & $r / f r$ & $I V / \Delta$ & آزمايش & \multirow{2}{*}{ ييش آزمون } & \multirow{4}{*}{ فرانخر انى منفى } & \\
\hline$\cdot / r V r$ &.$/ 90$ & $r / T r$ & $19 / 40$ & كو اه & & & \\
\hline - MFG &.$/ 949$ & r/Ar & $11 / \mathrm{V}$ & آزمايش & \multirow{2}{*}{ يس آزمون } & & \\
\hline - /FFA & $\cdot / 9 \Delta \Delta$ & $r / 90$ & 19/VQ & كواه & & & \\
\hline$\cdot / 1 \wedge \Delta$ & . /9MF & $r / \mu r$ & $19 / 1$ & آزمايش & \multirow{2}{*}{ بيش آزمون } & \multirow{4}{*}{ باورهاى خر افه } & \\
\hline • &.$/ 94 \Delta$ & $r / r q$ & $10 / 10$ & كواه & & & \\
\hline$\cdot / \cdot 11$ &.$/ 91 V$ & $r / \cdot 1$ & $11 / \wedge \Delta$ & آزمايش & \multirow{2}{*}{ يس آزمون } & & \\
\hline •/OrA &.$/ 99$ & r/Ar & $10 / \Gamma$ & كواه & & & \\
\hline$\cdot / \mu \cdot 1$ & $\cdot / A F \Delta$ & r/AT & $r M / 10$ & آزمايش & \multirow{2}{*}{ ي ييش آزمون } & \multirow{4}{*}{ آمادگى هيجانى } & \\
\hline . & . /949 & r/Dr & $r 1 / 9$ & كواه & & & \\
\hline$\cdot / 49 \Lambda$ & $\cdot / 9 \Delta \wedge$ & $r / F \Lambda$ & $r q / \cdot \Delta$ & آزمايش & \multirow{2}{*}{ يس آزمون } & & \\
\hline$\cdot / \mathrm{VAN}$ & $\cdot / 971$ & $r / f$ & $Y I / V$ & كواه & & & \\
\hline$\cdot / 9$ &.$/ 9 \vee \wedge$ & $\wedge / \wedge 9$ & $r / / 10$ & آزمايش & \multirow{2}{*}{ ييش آزمون } & \multirow{4}{*}{ توانايى واكنش دادن } & \\
\hline$\cdot / l \Delta r$ &.$/ 94$ & A/Vr & rN/lQ & كواه & & & \\
\hline$\cdot / 1991$ & $\cdot / 9 V \Delta$ & $9 / \Delta r$ & $\Delta \Delta / V \Delta$ & آزمايش & \multirow{2}{*}{ بس آزمون } & & \\
\hline$\cdot / \Delta \wedge F$ &.$/ 994$ & $\Lambda / T V$ & $r q / 4$ & كواه & & & \\
\hline$\cdot / 111$ & $\cdot / 9 V r$ & $9 / 94$ & $r \Delta / F \Delta$ & آزمايش & ييش آزمون & \multirow[t]{4}{*}{ كارايى و اصالت } & \\
\hline$\cdot / 1 / \Delta$ &.$/ 9 V Y$ & $9 / \cdot V$ & r\&/A & كواه & & & \\
\hline$\cdot / 9 \wedge F$ & $\cdot / 99 V$ & $V / .9$ & $r v$ & آزمايش & \multirow{2}{*}{ يس آزمون } & & \\
\hline . $/ 9 Y 9$ & $\cdot / 91$ & $9 / . F$ & $r V / 9 \Delta$ & كواه & & & \\
\hline
\end{tabular}

نمرات در هر دو متغير فراشـــاخـت و خلاقيت هيجانى در هر دو مرحله

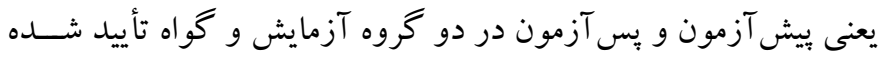

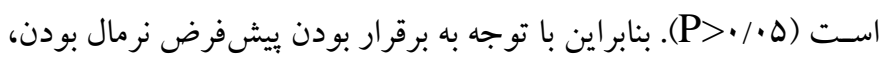

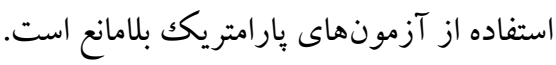

همان گونه كه در جدول Y مشاهده مىشود، ميانگين نمرات متغيرهاى

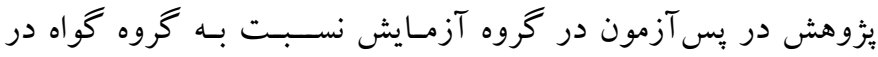
آزمونهاى فراشناخت و خلاقيت هيجانى، بهبود نشان داده است. همرجنين براى آزمودن فرض نرمال بودن از آزمون شـاييروويلكك استفاده شد كه كه 
همخنى واريانس متغيرهاى وابسـته نشــان داد كه واريانس فراشــناخت

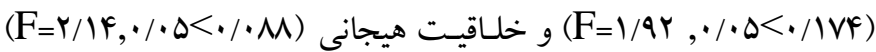
در گروه ها برابر است. در جدول با، نتايج تحليل كوواريانس تككمتغيرى

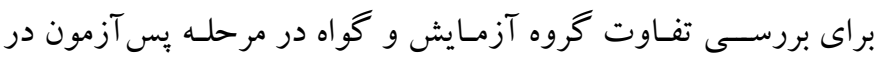
متغيرهاى فراشـناخت و خلاقيت هيجانى با كنترل بيش آزمون اين متغيرها ارائه شده است.
براى بررسى تأثير بسته آموزش شناختى - هيجانى - اجتماعى حافظه فعال بر فراشـناخت و خلاقيت هيجانى از تحليل كوواريانس تكك متغيرى

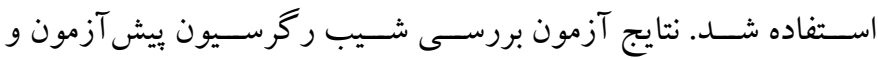

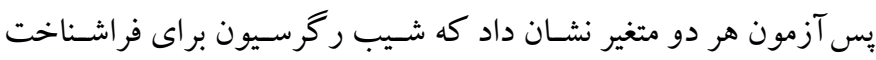

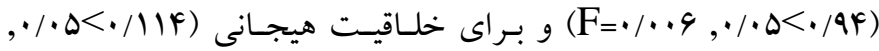

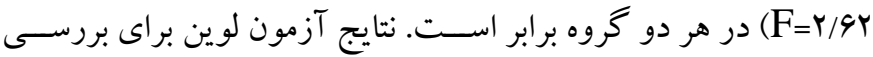

جدول r: نتايج تحليل كواريانس تكمتغيرى، تفاوت تروه آزمايش و كواه در فراشناخت و خلاقيت هيجانى

\begin{tabular}{|c|c|c|c|c|c|c|c|}
\hline اندازه اثر & $\mathbf{P}$ & Tاره F T & ميانكين مجذورات & درجه آزادى & مجموع مجذورات & منبع & متغير \\
\hline$\cdot / 9 \Delta F$ &.$/ \cdot 1$ & $V \cdot / \cdot r F$ & YF.F/QAF & 1 & YF. F/QAF & ي يش آزمون & \\
\hline \multirow[t]{2}{*}{$\cdot / N r$} & $\cdot / \cdot 1$ & $q F / Q F$ & RTG./GY & 1 & rYG./94 & عضويت گروهى & فراشناخت \\
\hline & & & $\mu F / \mu F$ & rv & $1 r V \cdot / V 94$ & خطا & \\
\hline$\cdot / \Delta Y V$ &.$/ \cdot 1$ & $41 / 19$ & FF. I/TMY & 1 & FF. I/TMY & ي يش آزمون & \\
\hline \multirow[t]{2}{*}{ - N VEG } & 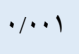 & $1 \cdot N / 91 F$ & $119 \cdot r / A F F$ & 1 & $119 \cdot$ r/AFF & عضويت گروهى & خلاقيت هيجانى \\
\hline & & & $1.9 / 1 \mathrm{MG}$ & rv & $M 9 \Delta r / 91 \Lambda$ & خطا & \\
\hline
\end{tabular}

كواه (M/M/4) اسـت كـه با توجه به آماره F در هر دو متغير در ســطح

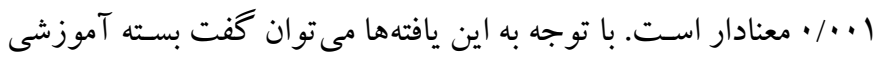

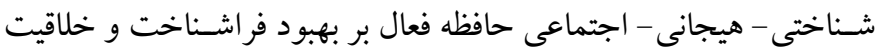
هيجانى دانش آموزان دختر بايه ينجم دبستان مؤثر بوده است.

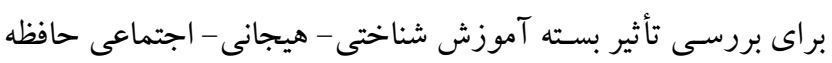

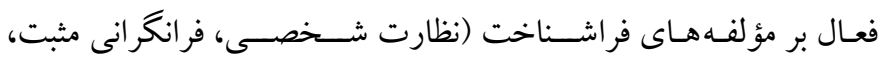
فر انخر انى منفى، باورهاى خر افى) و مؤلفه هاى خلاقيت هيجانى (آمادكى مورى هيجانى، توانيى واكنش دادن، كارايى و اصالت) دانش آموزان، از تحليل

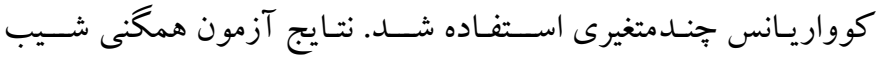

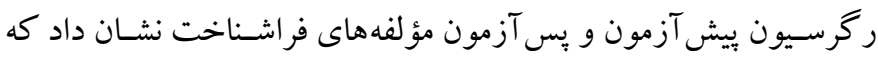

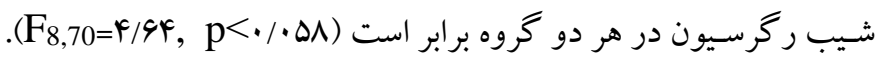

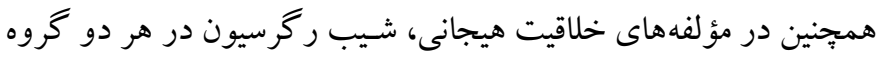

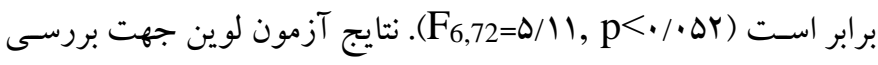

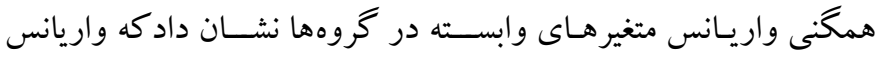

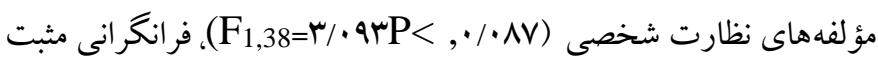

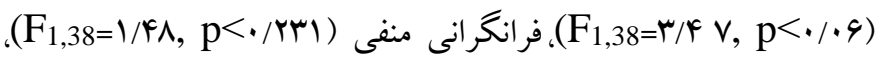
باورهاى خرافى (D)
براســاس يـافته هاى به دســت آمده در جدول لَ، آمارهF در مرحله

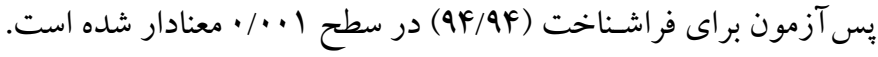
اين يافته ها نشـانكر آن اسـت كه بين دو گروه آزمايش و گو اه در ميزان فراشناخت تفاوت معنادارى وجود دارد. اندازه اثر آلمr • نيز نشان مىدهد

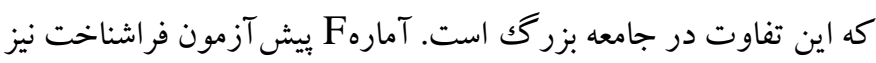

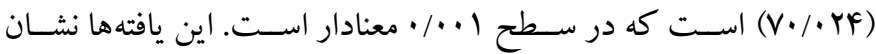

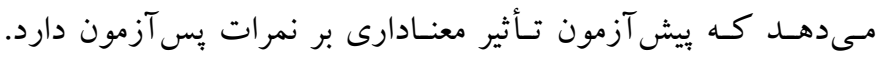
همجنين نتايج جدول ب نشان داده است كه آماره F در مرحله بس آزمون

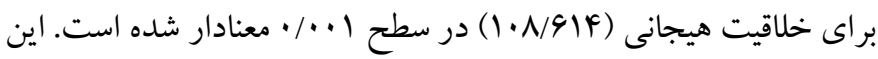

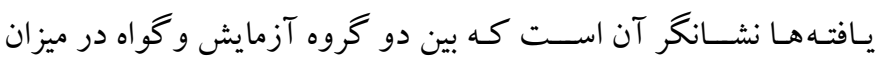

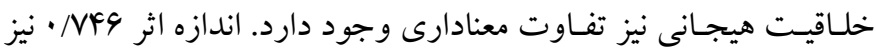
نشـان مىدهد كه اين تفاوت در جامعه بزرگك است. آماره Foيش آزمون

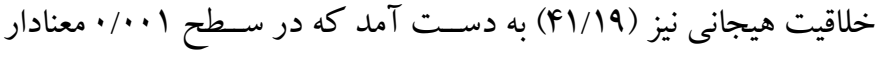
است و نشان مىدهد كه يِيش آزمون تأثير معنادارى بر نمرات پِ بس آزمون

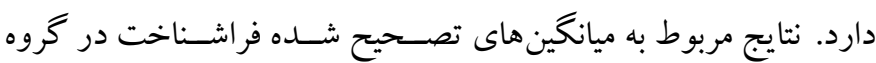

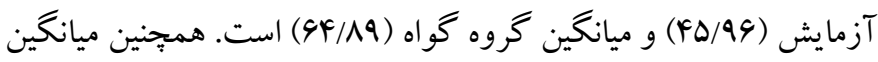

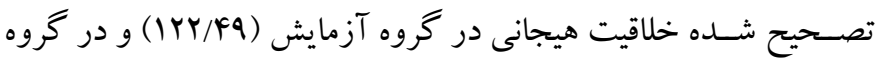


متغيرهاى وابسته در هر دو گروه برابر است. پِ از بررسى پيشفرض هاى

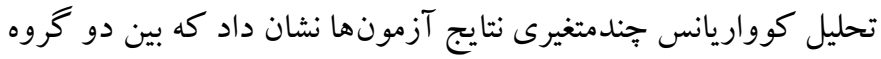

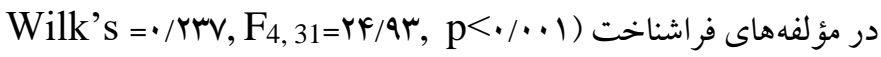
Fambda (Wilk’s Lambda=•/r·q,

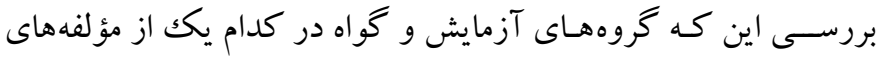

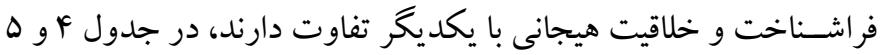
نتايج تحليل واريانس تككمتغيرى گزارش شده است
برابر اسـت. همجينين واريـانس مؤلفـهــاى آمادكى هيجانى (199/•> ,

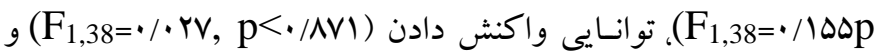

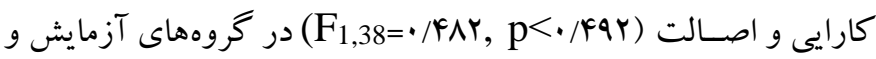

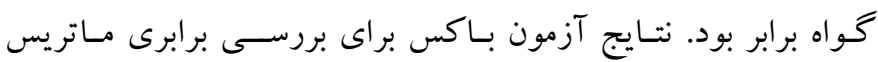

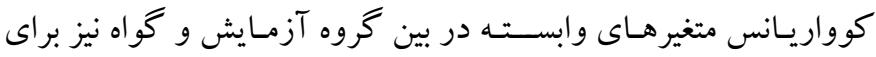

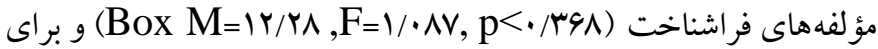

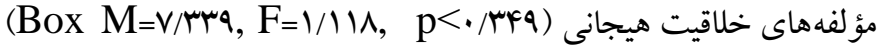
بـه دســت آمـد كه در هر دو تحليل نشــان داد كه ماتريس كوواريانس

جدول ع: نتايج تحليل واريانس تككتغيرى مربوط به تفاوت كروه آزمايش و كواه در مؤلفههاى فراشناخت

\begin{tabular}{|c|c|c|c|c|c|c|c|}
\hline اندازه اثر & $P$ & $\mathbf{F}$ & خطاى استاندارد & تفاوت ميانكين & ميانكين & كروه & متغيير \\
\hline$\cdot / 4 q$ &.$/ \cdot 1$ & $r \mu / . r$ & $1 / 10$ & $-F / \& V$ & $\begin{array}{l}1 Y / 9 \Delta \\
I V / F \cdot r\end{array}$ & 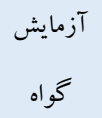 & نظارت شخصى \\
\hline$\cdot 109$ &.$\cdot \cdot 1$ & $\mathrm{kr} / 9 \mathrm{~F}$ & $1 / F Y$ & $-\xi / V \Lambda$ & $\begin{array}{l}1 . / .91 \\
1 \mathrm{~F} / \mathrm{AF}\end{array}$ & كواه & فرانخرانى مثبت \\
\hline .194 &.$/ .1$ & $\Delta N / 19$ & $\cdot / 9 V$ & $-\Delta / \Delta r$ & $\begin{array}{l}11 / 49 \\
19 / 99\end{array}$ & كواه & فر انگگر انى منفى \\
\hline$\cdot / A r$ &.$/ .1$ & $r \Delta / Y \Lambda$ & $\cdot / 9 r$ & $-F / T V$ & $\begin{array}{l}\mid 1 / F F \\
|\Delta / V|\end{array}$ & كوايش & باورهاى خر افى \\
\hline
\end{tabular}

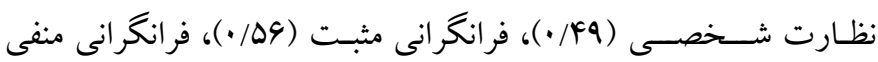

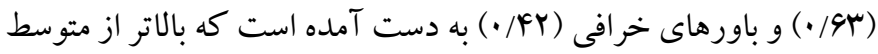

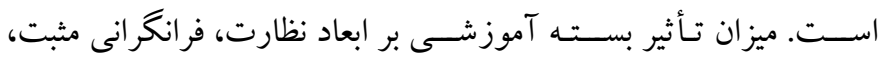

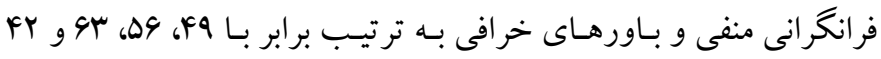

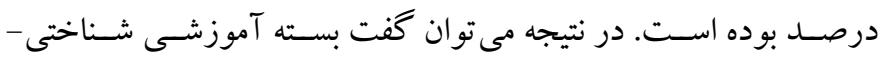

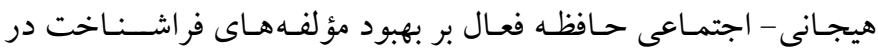
دانش آموزان دختر بايه بنجم دبستان مؤثر است. در جدول هـ نتايج تحليل

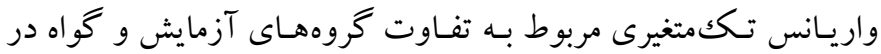
مؤلفه هاى خلاقيت هيجانى گزارش شده است.

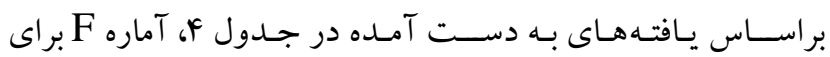

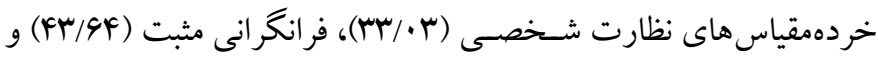

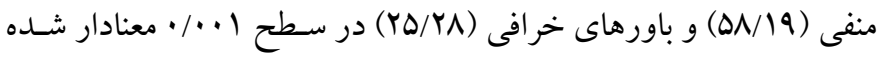

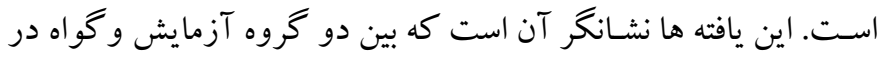

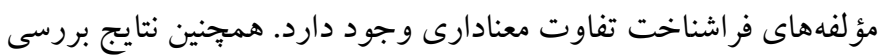

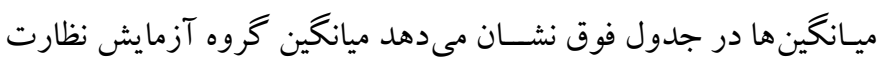

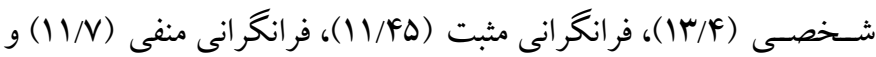

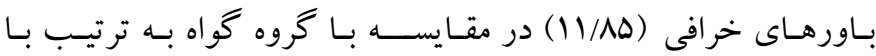

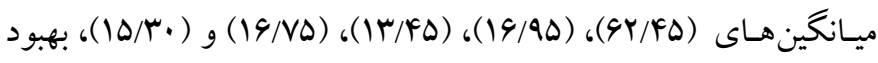
يافته اسـت. همجِين اندازه اثر در جدول f نشــان مىدهد كه اندازه اثر 
جدول 0: نتايج تحليل واريانس تككتغيرى، تفاوت كروه آزمايش و كواه در مؤلفههاى خلاقيت هيجانى

\begin{tabular}{|c|c|c|c|c|c|c|c|}
\hline اندازه اثر & $\mathbf{P}$ & $\mathbf{F}$ & خطاى استاندارد & تفاوت ميانكين & ميانكين & كروه & متغيير \\
\hline .199 & $\cdot / \cdot 1$ & $99 / 01$ & $1 / .9$ & $V / \Delta 1$ & $\begin{array}{l}r q / 1 r \\
r / / q r\end{array}$ & كو آزمايش & آماد گى هيجانى \\
\hline$\cdot / N$ & $\cdot / \cdot 1$ & $Q \Lambda / F \wedge$ & $r / \Delta r$ & $19 / 0 \mathrm{~V}$ & $\begin{array}{l}\Delta \Delta / \wedge q \\
\Gamma Q / Y q\end{array}$ & كو آزمايش & توانايى واكنش دادن \\
\hline$\cdot / \Delta \Lambda$ & $\cdot / \cdot 1$ & FV/9D & 1/V9 & Q/AV & $\begin{array}{l}r V / F I \\
r V / \Delta F\end{array}$ & كو آزمايش & كارايى و اصالت \\
\hline
\end{tabular}

سويى هم با نتايج برخى از يثزوهشها كه بر اثربخشى آموزش راهبردهاى

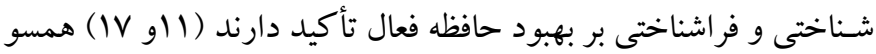

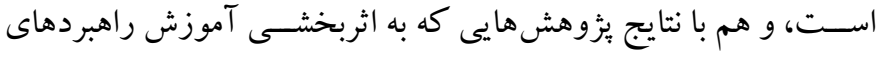

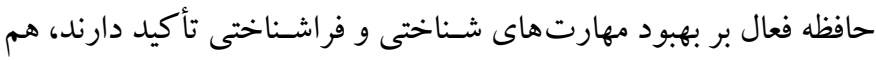

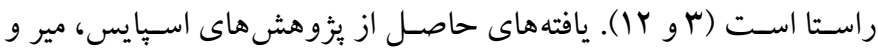

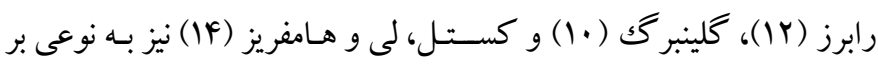
اثربخشـى برنامههاى آموزشـى حافظه فعال بر بهبود مهارتهاى فرا شــاختى

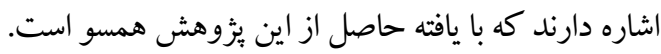

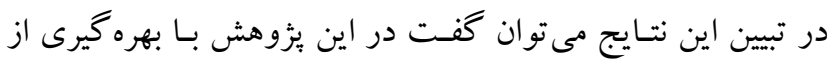
مبانى علمى در جهت تدوين و توليد بسته آموزشسى شناختى - هيجانى -

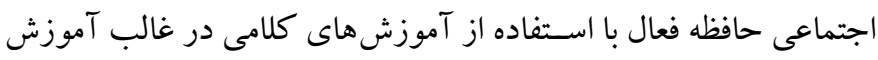

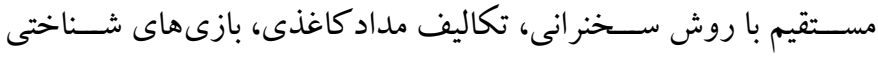

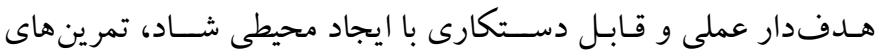

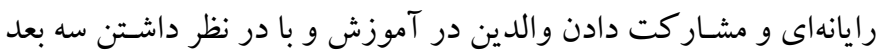

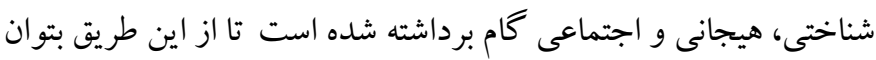

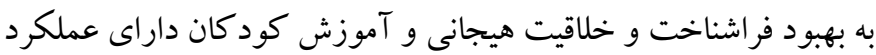

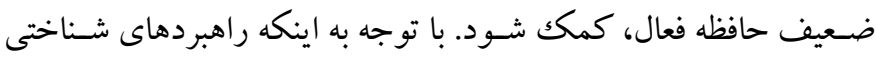
شامل حافظه، توجه، دريافت، نخهدارى و بردازش اطلاعات و راهبردهاى

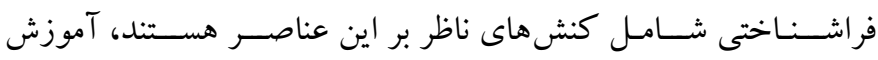

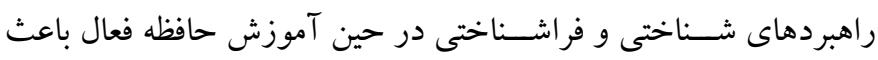

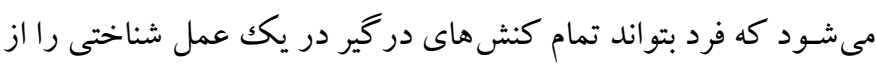

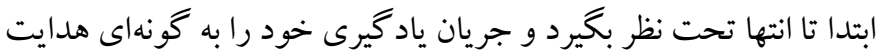

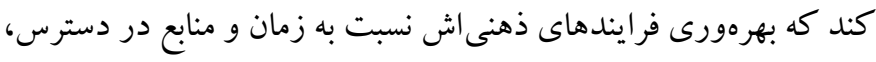

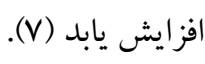

براســاس يـافتههــاى بـهـ دســت آمـده در جـدول ه، آماره F براى

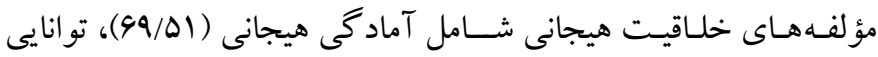

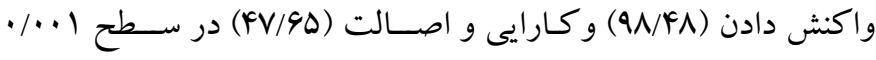
معنادار شده است. اين يافتهها نشانكر آن است كه بين دو گروه آزمايش

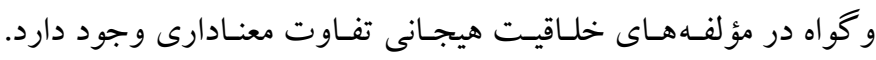

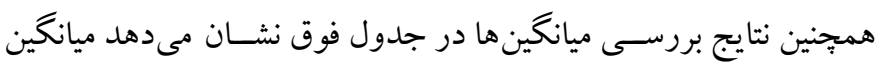

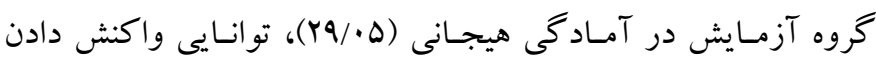
(هD/VD)

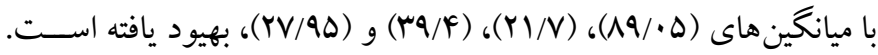

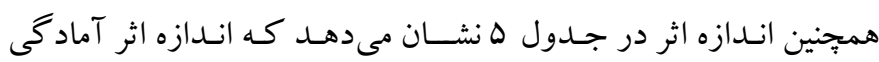

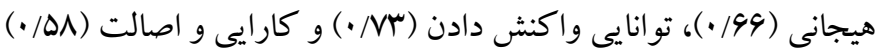
به دسـت آمده است كه همخى بالاتر از متوسط هستند و ميزان تأثير بسته

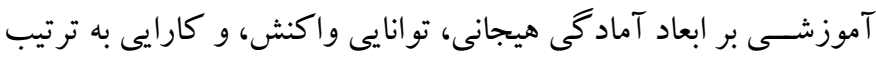

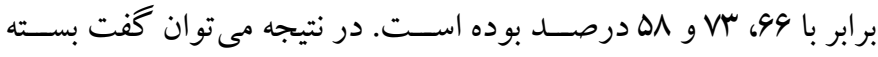

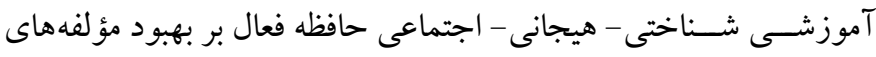

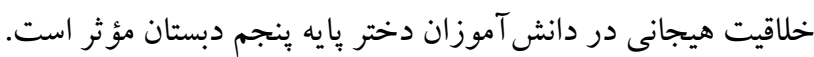

\section{بحث و نتيجه تيرى}

اين برزوش با هدف بررسـى تأثير بسـته آموزشسى شـناختى - هيجانى -

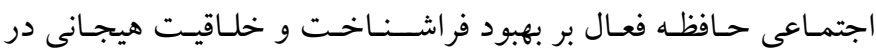

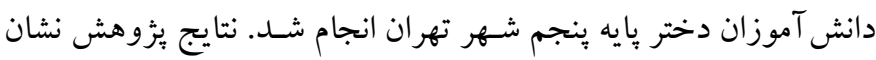

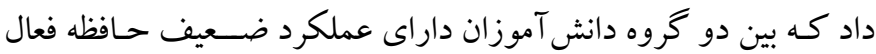
تفـاوت معنـادارى وجود دارد؛ بـدين معنا كه ·r جلســهـ آموزش بســـه شـناختى - هيجانى - اجتماعى حافظه فعال، به افزايش معنادار فر اشـناخت در بين تمـامى آزمودنىها در مرحله يس آزمون منجر شــــــ اين نتيجه از 
باعث اسـتفاده بهتر دانش آموزان از ظرفيتشـــاسـى حافظه فعالشـــان

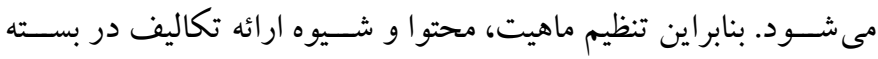

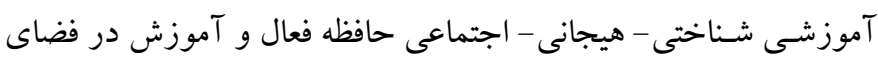

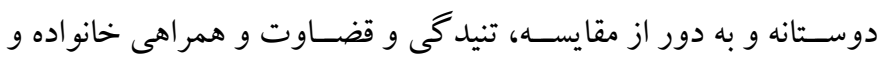

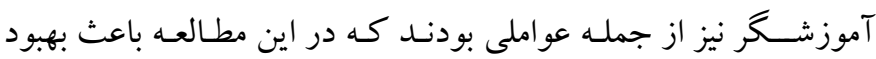
فر اشناخت شدهاند. يكى ديخر از نتايج به دسـت آمده از ئزوهش حاضر، اثر بخشى بسته

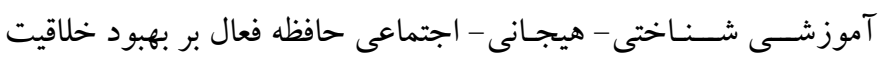

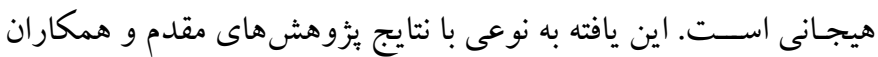

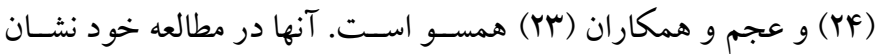

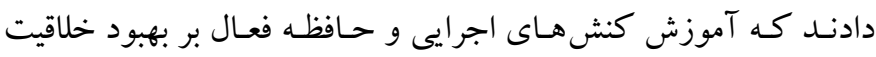
هيجانى و شـناختى مؤثر اسـت. در همين راستا نتايج مطالعات انجام شده

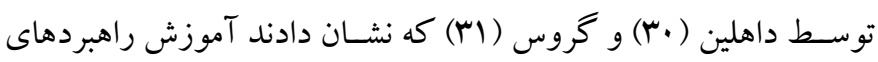
تنظيم هيجـان بر بهبود خلـاقيـت هيجانى اثربخش اســت، نيز با يافتهاى

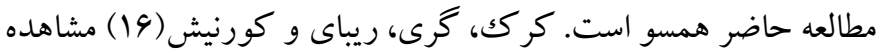

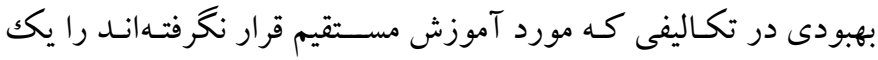
ويز گى مطلوب برنامه هاى آموزشى شـناختى مى داند كه اثربخشسى اين

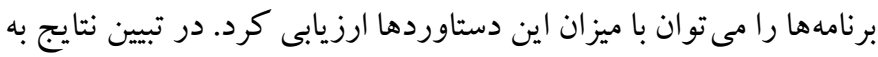

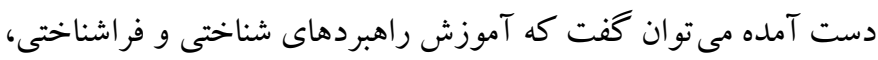

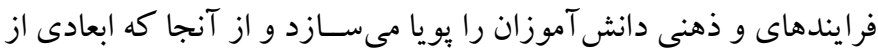

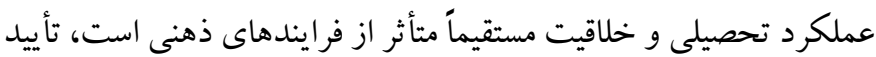
تأثير اين آموزشها بر خلاقيت، دور از انتظار نيست. در واقع آموزش اين

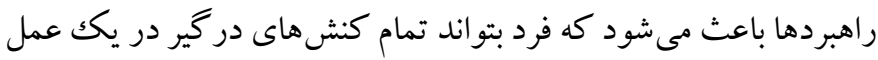

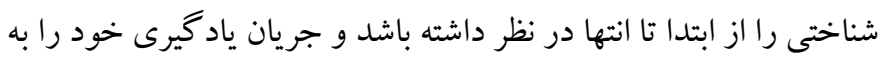

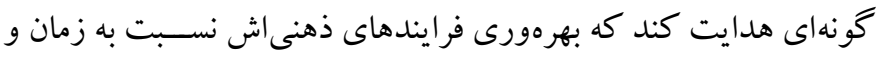

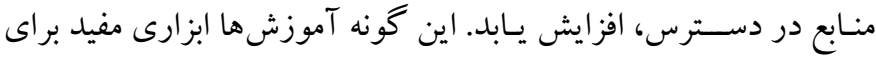

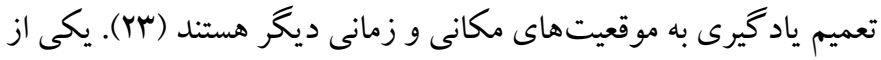

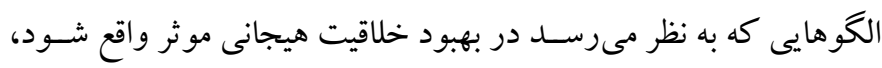

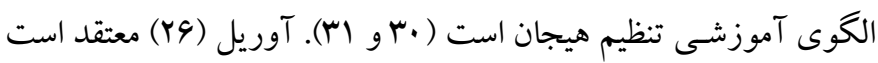
افراد با خلاقيت هيجانى قادر هستند به طور صحيح موقعيت را ارزيابى و احسـاسـات خود را ماهرانه بيان كنند. در سـالهاى اخير آموزش تنظيم

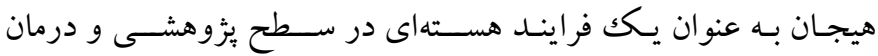

آموزشهاى متمركز بر حافظه فعال از اين جهت اهميت دارند كه در

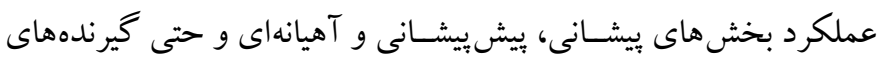

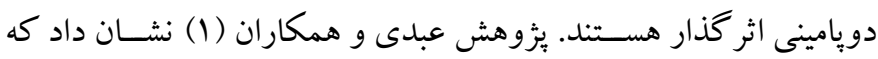
بازى هاى شناختى و فر اشناختى منجر به كو تاه شدن زمان واكنش و بهبود سرد

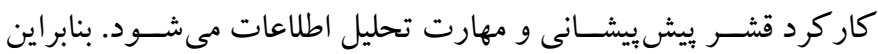

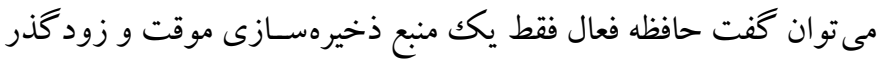
نيسـت، بلكه با دســكارى اطللاعات، آنها را به صــورت فعال به به حافظه

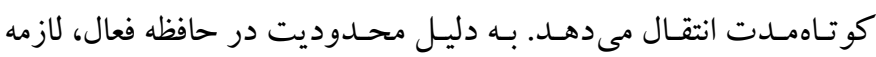

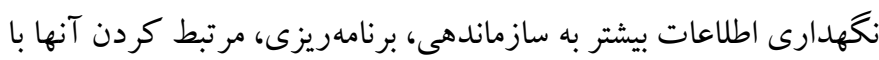

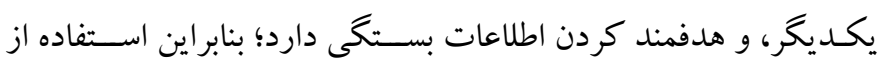
راهبردهاى شـناختى و فراشـناختى در فرايند ياد گيرى و يادآورى، تأثير

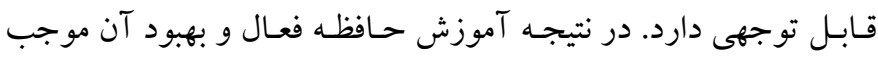
ياد گيرى، ارتقاء و كاربرد بيشتر راهبردهاى شناختى و فراشناختى مئى شورد

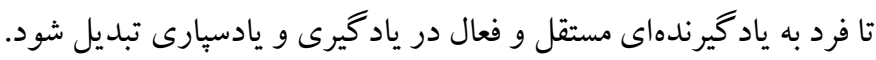
در واقع اكتسـاب و استتفاده از مهارتهاى شـناختى و فراشناختى، فرايند يادسبارى را سادهتر مى كند.

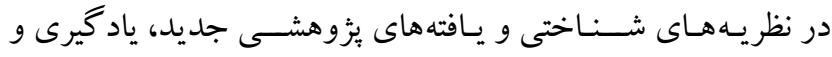

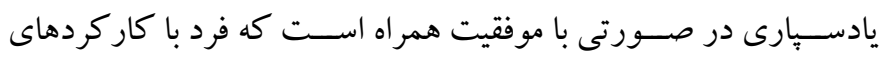

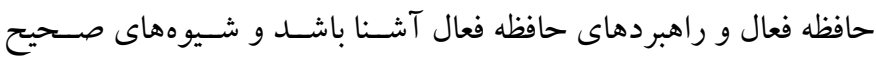

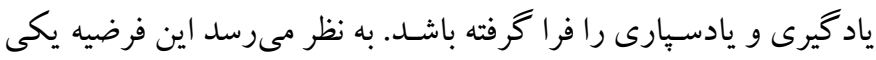
از شـاخصهاى مناسـب براى تشخيص ياد گيرنده ماهر از غير ماهر باشد؛

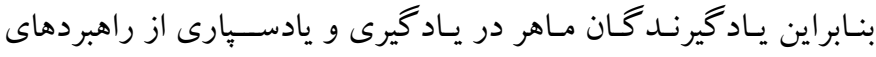

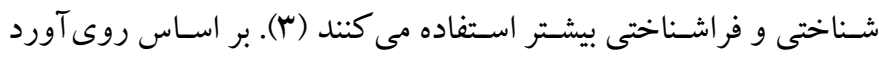

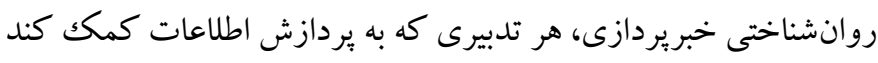

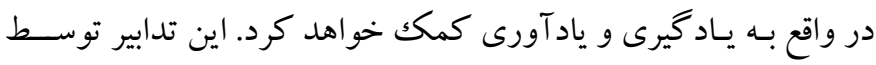
روانشناسان خبريردازى، راهبردهاى شناختى و فر اشناختى ناميده شدهاند

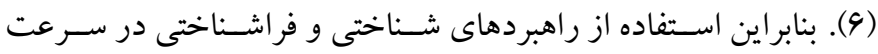

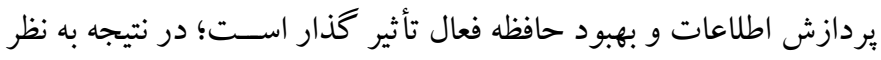
مىرســـ ارتبـاطى دو طرفـه ميـان حافظه فعال و راهبردهاى شــناختى و

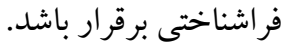
نتايج مطالعات آوتين و كرويزت (سا) نشــان مىدهد كه ايجاد يكك محيط روانى امن در كلاس با تغيير در تفسير فراشناختى دشوارى تكليف، 
هيجانى - اجتماعى حافظه فعال در بهبود خلاقيت هيجانى مؤثر واقع شـده

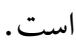

از طرفى تورنس (19) معتقـــ اســت كه عوامل هيجانى نه تنها باعث

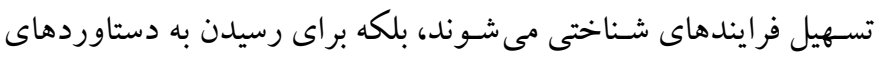

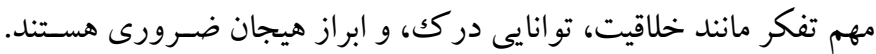

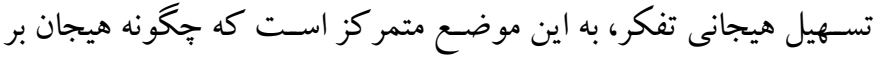

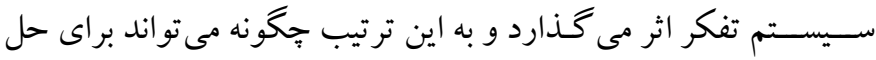

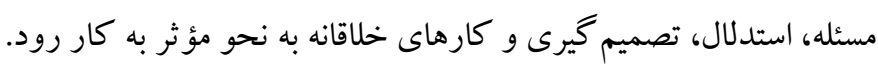

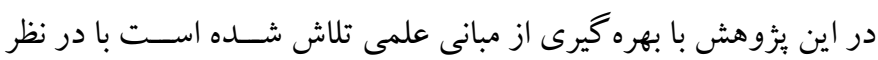

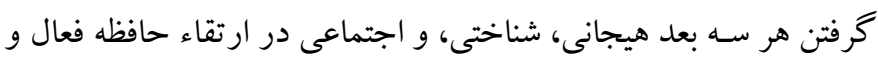

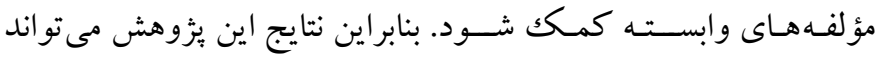

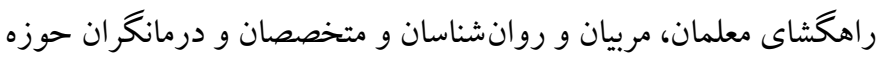

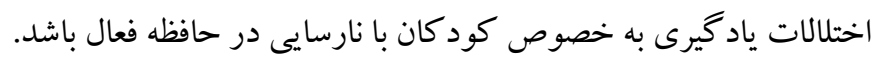
اين بزوهش با محدوديت هايى مانند عدم مشــاركت دادن بِـــران

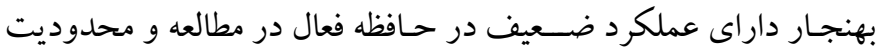
سنى افراد آزمودنى همراه بود. عدم دسترسى به ابزارهاى عصب دشناختى

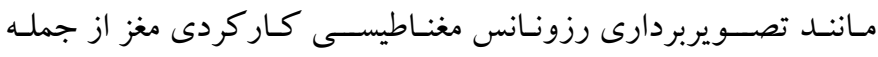
محدوديت هاى ديخر يثوهش حاضـر بوده اسـت، زيرا وجود اين ابزارها باعث مى شـود تا تغييرات مغزى و عصسبـشــناختى را در مر احل مداخله مشاهده كرد. در نتيجه يِينهاد مى شود در يزوهش هاى آتى از ابزارهاى عصبشناختى نيز استفاده شود. همجنين بيشنهاد مى شود در بثزوهشهاى

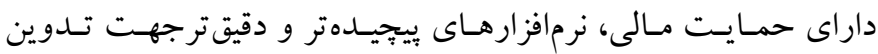

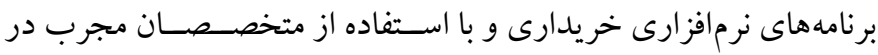

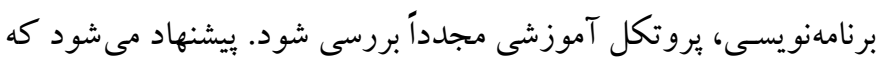

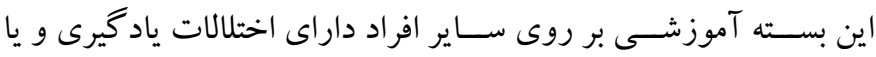
نارسايى در توجه نيز اجراو اثربخشى آن بررسى شود. همجنين بايد توجه داشــت كه اين يثزوهش در حجم نمونه كوجيك و و آن هم دانش آموزان

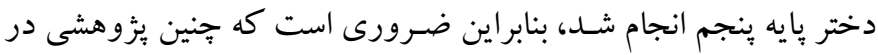

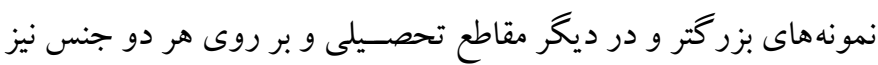
انجام شود. همجنين بيشنهاد مى شود معلمان و متخصصان تعليم و تربيت و سـاير متخصصـان كه در ارتباط مستقيم با دانش آموزان هستتند ضمن

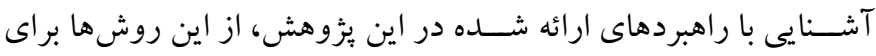

آسـيبـهاى روانى، مورد هدف واقع شــده اســت (YN). آموزش تنظيم

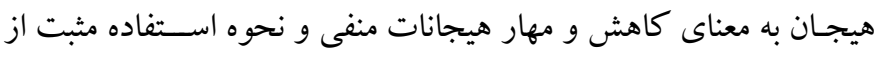

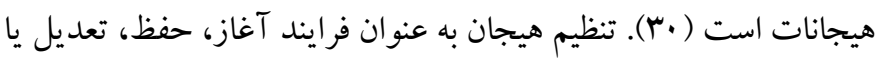
تغيير در بروز، شــــت يـا اســتمرار احســاس درونى و هيجان مرتبط با فرايندهاى اجتماعى، روانى و فيزيكى در به انجام رساندن اهداف تعريف

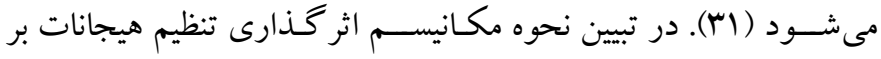
خلـاقيـت هيجـانى همجينين مى توان به رابطه هوش هيجانى و خلاقيت نيز

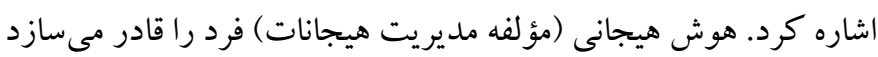

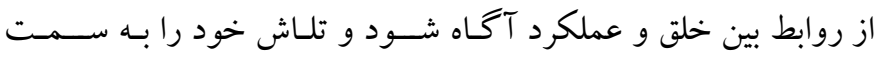

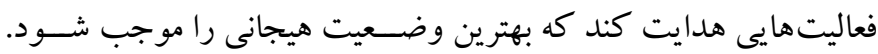
همجنين هوش هيجانى شخص را قادر مى سازد خلق مثبت را حفظ و آن

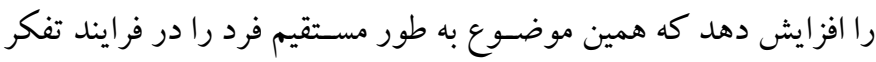
خلاق هيجانى، مشــار كت مىدهد (YN). مديريت هيجانى در توانايى فرد

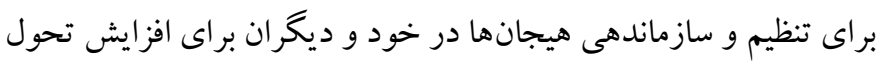

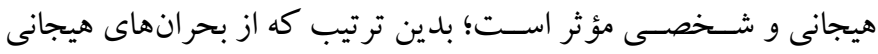

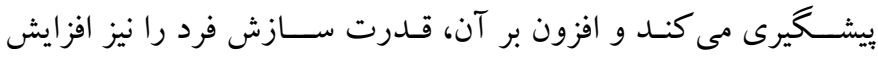
مىدهد؛ بنابر اين مستقيماً به كاهش مشكلات بين شخصى و و بهبود كيفيت روابط اجتمـاعى منجر مى شــود (YY). همين افزايش قدرت ســازش در

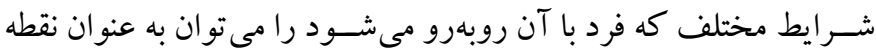
اصسلى ارتباط بين تنظيم هيجانى و خلاقيت هيجانى دانسـت زئه زير ايكى از

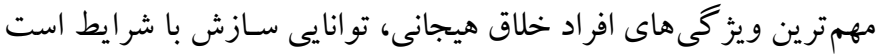

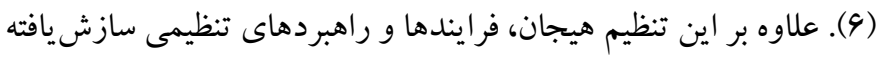

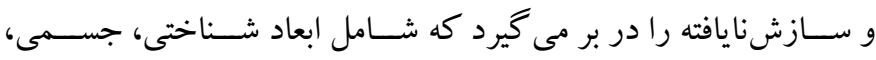
اجتماعى، و رفتارى مى شود. جنبه هاى شناختى تنظيم هيجان همانند ديخر

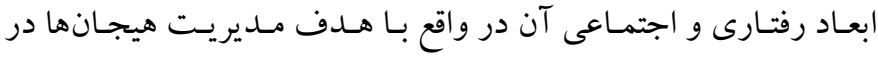

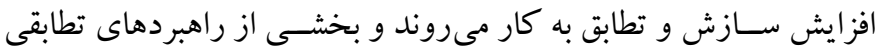
هستند كه با تجربه و درمان ناراحتى هاى هيجانى و جسمانى مرتبط هستند

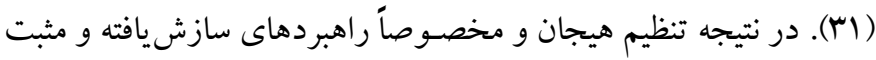
تنظيم هيجان باعث كاهش احساسات منفى و افزايش احساسات مثبت و رفتار سـازشيافته در افراد مى شـود و همان طور كه اشـاره شد، سازش با شـر ايط، از مشـخصـه هاى افر اد خلاق هيجانى است. با توجه به اين موارد

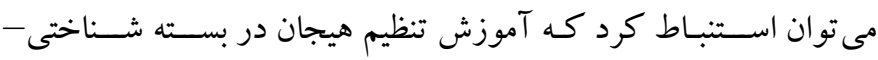


حامى مالى: اين مطالعه در قالب رسـاله دكتراى نويسـنده نخسـت اين مقاله به طور مستقل و بلدون حامى مالى انجام شده است.

نقش هر يكك از نويسند كان: نويسنده نخست اين مقاله خانم مز كان حسنى به عنوان مجرى اصـلى اين مطالعه، تحليل دادهها، و نوشـتن متن مقاله؛ نويســـده دوم آقاى محمد على نادى به عنوان اسـتاد راهنما، وير اسـتار علمى، و نويســنده مســول؛ و نو يسـنده سـوم دكتر ايلناز سجاديان به عنوان استاد مشاور و ويراستار علمى اين مقاله، نقش داشتهاند. تضاد منافع: اين يثوهش براى نو يسند گان هيج گونه تضاد منافع به دنبال نداشته است. تشكر و قدردانى: بدين وسيله از استادان راهنما و مشاور اين مطالعه، دانش آموزان،

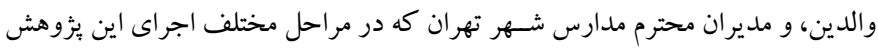
به ما كمك كردند، تشكر و قدردانى مى شود.
بهبود عملكرد حافظه فعال دانش آموزان با عملكرد تحصـيلى و شـناختى ضـعيف، اسـتفاده كنند. متخصــصــان تعليم و تربيت حتى مى توانند به صورت كاربردى و قابل استفاده به والدين كود كان آموزش دهند تا در تعامل دوجانبه، يِامدهاى نارسايى در حافظه فعال دانش آموزان را كاهش دهند. ملاحظات اخلاقى ييروى از اصـول اخلاق يثزوهش: اين يُزوهش با كد رسـاله ب...

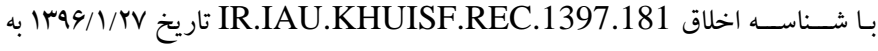
تصـويب رسيده اسـت و مجوز اجراى آن توسط سازمان كل آموزش و يرورش استان تهران صـادر شـده اسـت. همجنين سـاير ملاحظات اخلاقى مانند رضـايت افراد نمونه و والدين آنان در اين مطالعه كاملاً رعايت شده است. 


\section{References}

1. Abdi A, Arabani Dana A, Salehi j, Parand A. The Effect of Cognitive Computer Games on Working Memory, Attention and Cognitive Flexibility in Students with Attention Deficit/Hyperactivity Disorder. Journal of Exceptional Children. 2019; 14: 19-33. [Persian]. [Link]

2. Narimani M, Mohammad Amini Z, Zahed A, Abolghasemi A. A comparison of effectiveness of training self-regulated learning strategies and problem-solving on academic motivation in male students with academic procrastination. Journal of school psychology. 2015; 4 (1): 156-164. [Persian]. [Link]

3. Yarmohammadian A, Ghamarani A, Seifi Z Arfa M. Effectiveness of cognitive strategies training on memory, reading performance and speed of information processing in students with dyslexia. Journal of Learning Disabilities. 2015; 4(4): 101-117. [Persian]. [Link]

4. Desoete A, Ozsoy G. Introduction: Meta cognition, more than the longs monster? International Electronic Journal of Elementary Education. 2009; 2(1): 1-6. [Link]

5. Ashoori J, Azadmard SH, Abkenar J, MoeiniKia M. A prediction model of academic achievement based oncognitive and metacognitive strategies, achievement goals orientation and spiritual intelligence in biology. Journal of school psychology. 2014; 2(4): 170-178. [Link]

6. Saif AA. Modern educational. Tehran, AGAH Publication; 2013, PP: 78-91. [Persian].

7. Karami J, Momeni KH, Abbasi Z. The Effectiveness of Active Metacognitive Strategies on Performance (Reading, Accuracy, Speed, and Perceptions) Dyslexic Students. Journal of Psychology Achievements Magazine (Educational Sciences and Psychology).2015; 24(4): 5168. [Persian]. [Link]

8. Vitae T. Meta cognition is the awareness and control of one's own cognition. University of Maryland. 2010; (43):13-17. [Link]

9. Shiran A, Breznitz Z. The effect of cognitive training on recall range and speed of information processing in the working memory of dyslexic and skilled readers. Journal of Neurolinguistics. 2011; 24(5):524-37. [Link]

10. Klingberg T. Training and plasticity of working memory. Trends in cognitive sciences. 2010; 14(7):317-24. [Link]

11. Ghamari Givi H, Narimani M, Mahmodi H. The effectiveness of cognition-promoting software on executive functions, response inhibition and working memory of children with dyslexia and attention dificit/ hyperactivity. Journal of Learning Disabilities. 2012; 1(2): 98-115. [Persian]. [Link]
12. Spiess MA, Meier B, Roebers CM. Development and longitudinal relationships between children's executive functions, prospective memory, and metacognition. Cognitive development. 2016; 38:99-113. [Link]

13. Autin F, Croizet Jc. Improving working memory efficiency by reframing metacognitive interpretation of task difficulty. Journal of experimental psychology 2012; 141(4): 610-618. [Link]

14. Castel A D, Lee SS, Humphreys K L. Memory Capacity, Selective Control, and Value-Directed Remembering in Children With and Without Attention-Deficit / Hyperactivity Disorder (ADHD). Neuropsychology, 2011; 25(1): 15-24. [Link]

15. Soleymani E, Abbasi M, toghyani E. The effectiveness of cognitive-metacognitive strategies on the performance of attention- memory of students with ADHD. Journal of Cognitive Strategies in Learning. 2017; 4(7): 1-21. [Persian]. [Link]

16. Kirk HE, Gray K, Riby DM, Cornish KM. Cognitive training as a resolution for early executive function difficulties in children with intellectual disabilities. Research in Developmental Disabilities. 2015; 38:145-60. [Link]

17. Asli Azad M, Faramarzi S, Arefi M, Farhadi T, Fakkar A. The effectiveness of meta-cognitive knowledge on reduced hyperactivity and improved attention in children afflicted with attention deficit and hyperactivity disorder (ADHD) in the primary school. Advances in Cognitive Science.2014; 16(1): 1-57. [Persian]. [Link]

18. Hennessey BA, Amabile TM. Creativity and Learning: What Research Says to the Teacher? National Education Association, Professional Library, PO Box 509, West Haven, CT 06516; 1987. [Link]

19. Torrance EP. Torrance tests of creative thinking: Normstechnical manual: Figural (streamlined) forms A \& B. Minnesota Press; 2007. [Link]

20. Guilford Pre Morris R G Rushe T, Woodruff PW R, Murray R M. Problem solving in schizophrenia: A specific deficit in planning ability. Journal of Schizophrenia Research. 2005; 14: 235-249ss. [Link]

21. Sternberg RJ. The nature of creativity. Creativity research journal. 2006; 18(1):87-98. [Link]

22. Mihalyi C. Creativity: flow and the psychology of discovering and Discovery and Invention. New York: Harper Perennial; 1996. ISBN 0-06-092820-4. [Link]

23. Ajam AA, Badnava S, Abdollahi M, Momeni Mahmouei H. The Relation between Emotional Creativity and Academic Enthusiasm in Public Health students in Gonabad. University of medical sciences. 2015; 8(4): 117. [Persian]. [Link] 
24. Moghdam A, Nikbakht A, Nik Neshan SH, Syadat A. The Relationship between Emotional Intelligence and Student Creativity. Quarterly Journal of Educational Psychology. 2007; 5(1): 99-112. [Persian]. [Link]

25. Manavipor D. The relationship between emotional creativity and cognitive creativity with metacognitive skills. Psychological research. 2009; 2(8): 63-72. [Persian]. [Link]

26. Avrill JR. Emotions as mediators and as Products of creative activity. In J. Kanfman and J.Baer, creativity across domains: faces of the muse. 2005; 1: 225-243. [Link]

27. Jowkar B, Alborzi M. The relation of character in personality with emotional and cognitive creativity. Journal of Psychological Studies. 2009; 6(11): 89-109. [Persian]. [Link]

28. Irecevic Z, Brackett MA, Mayer YD. Emotional and intelligence creativity. Journal of Personality. 2007; 5(2): 199-235. [Link]

29. Kienitz E, Quintin EM, Saggar M, Bott NT, Royalty A, Hong DW, Liu N, Chien YH, Hawthorne G, Reiss AL. Targeted intervention to increase creative capacity and performance: a randomized controlled pilot study. Thinking Skills and Creativity. 2014; 13:57-66. [Link]

30. Dahlin K I E. Working memory and the effect on mathematical achievement in children with attention deficits and special needs. Journal of EduCation and learning. 2013; 2(1): 118-133. [Link]

31. Gross J J. Emotion regulation: taking stock and moving forward. Emotion. 2013; 13(3): 359-365. [Link]

32. Khodadadi M, Mashhadi A, Amani H. Working Memory Training Software. Tehran: Sina Behavioral Sciences Research Institute; 2006; 6: 177-183 [Persian]. [Link]

33. Sadeghi A, Rabiee M, Abedi $M$. the validity and reliability of the Wechsler Intelligence Scale for Children- Fourth Edition(WISC-IV). Journal of
Developmental Psychology. 2011; 7(28): 47-55. [Persian]. [Link]

34. Bacow TL, Pincus DB, Ehrenvieche JT and Broody LR. The metacognitions questionare for chidren: development and validation in a clinical sample of children and adolescents with anxiety disorders. Journal of Anxiety Disord. 2009; 23(6): 727-36. [Link]

35. Taghavi MR, Alishahi M. Validity and reliability of children's manifest anxiety scale (CMAS). Journal of Psychology. 2003; 28(4): 342-375. [Persian]. [Link]

36. Hassani M, Nadi M, Sajjadian I. Examining the Effectiveness of the Cognitive-Emotional-Social Working Memory Training Intervention of on Cognitive Emotion Regulation of 5th Grade Female Elementary School Students in Tehran. Journal of Instruction and Evaluation. 2020; 12(47):39-66. [Link]

37. Schweizer S, Grahn J, Hampshire A, and Mobbs D, Dalgleish T. Training the emotional brain: improving affective control through emotional working memory training. Journal of Neuroscience. 2013 Mar 20; 33(12):5301-11. [Link]

38. Samimi Z, Hasani J, Kord Tamini M, Parooi M. The Effectiveness of Emotional Working Memory Training on Execution Functions of Adolescents with Post-Traumatic Stress Disorder. Iranian Psychologists. 2016; 13(49): 95-115. [Persian]. [Link]

39. Kord Tamini M, Mashhadi A, Salehi Fedri J, Hassani J. Effectiveness of Emotional Working Memory Training on Improving Cognitive Control in individuals with High Trait Anxiety. Journal of Cognitive Psychology. 2016; 3(3-4): 31-40. [Persian]. [Link]

40. Tempesta D, De Gennaro L, Presaghi F, Ferrara M. Emotional working memory during sustained wakefulness. Journal of sleep research. 2014; 23(6):64656. [Link] 